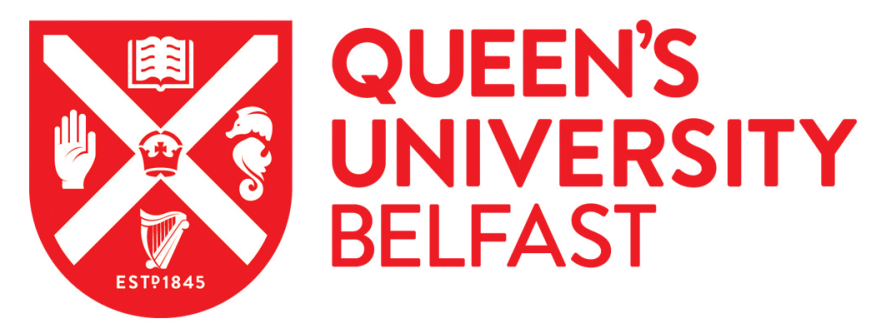

\title{
Development and evaluation of a novel integrated anti-icing/de-icing technology for carbon fibre composite aerostructures using an electro- conductive textile
}

Falzon, B. G., Robinson, P., Frenz, S., \& Gilbert, B. (2015). Development and evaluation of a novel integrated anti-icing/de-icing technology for carbon fibre composite aerostructures using an electro-conductive textile. Composites Part A: Applied Science and Manufacturing, 68, 323-335.

https://doi.org/10.1016/j.compositesa.2014.10.023

Published in:

Composites Part A: Applied Science and Manufacturing

Document Version:

Peer reviewed version

Queen's University Belfast - Research Portal:

Link to publication record in Queen's University Belfast Research Portal

\section{Publisher rights}

Copyright 2014 Elsevier.

This manuscript version is made available under a Creative Commons Attribution-NonCommercial-NoDerivs License

(https://creativecommons.org/licenses/by-nc-nd/4.0/), which permits distribution and reproduction for non-commercial purposes, provided the author and source are cited.

\section{General rights}

Copyright for the publications made accessible via the Queen's University Belfast Research Portal is retained by the author(s) and / or other copyright owners and it is a condition of accessing these publications that users recognise and abide by the legal requirements associated with these rights.

\section{Take down policy}

The Research Portal is Queen's institutional repository that provides access to Queen's research output. Every effort has been made to ensure that content in the Research Portal does not infringe any person's rights, or applicable UK laws. If you discover content in the

Research Portal that you believe breaches copyright or violates any law, please contact openaccess@qub.ac.uk. 


\section{Accepted Manuscript}

Development and evaluation of a novel integrated anti-icing/de-icing technology for carbon fibre composite aerostructures using an electro-conductive textile

Brian G. Falzon, Paul Robinson, Sabine Frenz, Brian Gilbert

PII:

S1359-835X(14)00335-2

DOI: http://dx.doi.org/10.1016/j.compositesa.2014.10.023

Reference: JCOMA 3763

To appear in:

Composites: Part A

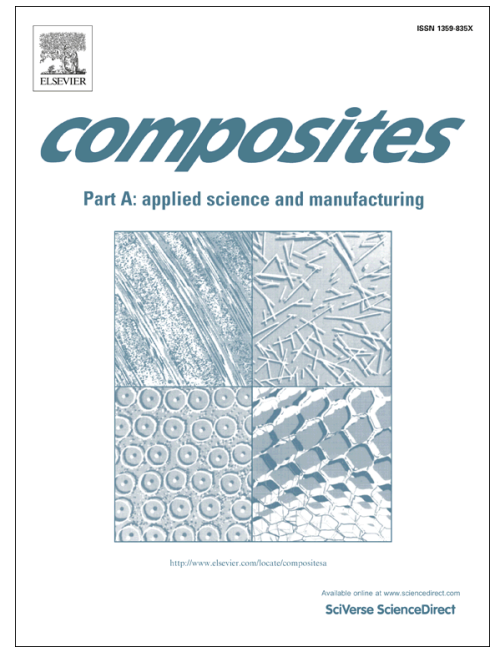

Received Date: $\quad 12$ April 2014

Accepted Date: $\quad 21$ October 2014

Please cite this article as: Falzon, B.G., Robinson, P., Frenz, S., Gilbert, B., Development and evaluation of a novel integrated anti-icing/de-icing technology for carbon fibre composite aerostructures using an electro-conductive textile, Composites: Part A (2014), doi: http://dx.doi.org/10.1016/j.compositesa.2014.10.023

This is a PDF file of an unedited manuscript that has been accepted for publication. As a service to our customers we are providing this early version of the manuscript. The manuscript will undergo copyediting, typesetting, and review of the resulting proof before it is published in its final form. Please note that during the production process errors may be discovered which could affect the content, and all legal disclaimers that apply to the journal pertain. 
Development and evaluation of a novel integrated anti-icing/de-icing technology for carbon fibre composite aerostructures using an electro-conductive textile

\author{
Brian G. Falzon*
}

School of Mechanical and Aerospace Engineering, Queen's University Belfast,

UK, BT9 5AH

Paul Robinson

Department of Aeronautics, Imperial College London, South Kensington,

UK, SW7 2AZ

Sabine Frenz

formerly of Imperial College London, now at Element, Hitchin, Hertfordshire, UK, SG4 OTW

\author{
Brian Gilbert
}

Assystem UK Ltd, Preston, UK, PR5 6FN

*Corresponding Author: b.falzon@qub.ac.uk, Tel: +44 (0)28 90975640 


\section{ABSTRACT}

The preliminary evaluation is described of a new electro-thermal anti-icing/de-icing device for carbon fibre composite aerostructures. The heating element is an electro-conductive carbon-based textile (ECT) by Gorix. Electrical shorting between the structural carbon fibres and the ECT was mitigated by incorporating an insulating layer formed of glass fibre plies or a polymer film. A laboratory-based anti-icing and de-icing test program demonstrated that the film-insulated devices yielded better performance than the glass fibre insulated ones. The heating capability after impact damage was maintained as long as the ECT fabric was not breached to the extent of causing electrical shorting. A modified structural scarf repair was shown to restore the heating capacity of a damaged specimen.

\section{KEYWORDS}

A. Smart materials; B. Electrical properties; B. Thermal properties; B. Damage tolerance

\section{Introduction}

The build-up of ice on aircraft wings can result in severe degradation in lift and loss of aircraft control [1]. Indeed, experimental and computational studies on the effects of ice accretion on aerodynamic surfaces continue to be active areas of research [2-5]. There are two established approaches for mitigating this problem; using an anti-icing system to prevent the formation of ice on the wing or other aerodynamic surface during flight, and de-icing, which is the removal of ice buildup, usually whilst the aircraft is stationary.

The most common anti-icing system on existing commercial airliners, with a predominantly metallic primary structure, uses hot air from the engine compressor stages which is 'bled' through a network of piping to vulnerable regions and expelled through small holes in the metallic wing skin, which is thereby heated by thermal conduction [6]. The air-bleed reduces the efficiency of the engines and the pipe network adds considerable weight and maintenance requirements. Another established approach, used on smaller commuter aircraft, is to use pneumatic bladders in regions which are most prone to ice build-up, primarily the leading edges. These are inflated to detach ice from critical locations and as such act more as de-icing devices. The dislodged ice debris may impact other parts of the aircraft structure or be ingested by the powerplants, damaging fan blades [7]. Since pneumatic technologies are activated once ice has started to form, some aerodynamic performance is sacrificed prior to de-icing. Due to weight and maintenance implications, anti-icing and de-icing systems are restricted to specific, albeit critical, regions and so ice can still accumulate at other sections of the lifting surface. 
De-icing of passenger aircraft is usually performed at airports by technical ground staff spraying the aircraft with a heated Newtonian anti-freeze fluid, usually a dilute solution of monopropylene glycol which is considered non-toxic. Once de-iced, the aircraft has to take-off within an allotted time-frame, otherwise the process needs to be repeated. If the aircraft is likely to be stationary for a longer period, a non-Newtonian glycol solution is applied, which is more viscous, forming a protective layer over the wing which is longer-lasting. Despite the stated non-toxicity of these fluids, concern has been raised by environmental groups on their safety upon entering water systems and some airports have implemented containment systems to prevent such contamination. Another technology which has been installed at a selection of U.S. airports involves the use of infrared energy, supplied from the burning of natural gas or propane, through a matrix of outlets distributed over a large canopy under which the aircraft is placed [8].

In recent years a number of alternative systems have been proposed which attempt to improve the power efficiency and operational effectiveness of anti-icing or de-icing. Electro-thermal systems which could be potentially utilised for both anti-icing and de-icing are based on the introduction of a resistive heating element within, or adhered to, the structure. Early examples on metallic aircraft involved the use of a metal foil as the heating element, bonded to the wing's surface. As the aerospace industry moves towards the increased use of carbon-fibre composite material in primary aerostructures, the use of metal foils presents particular challenges in ensuring a durable bond. Hung et al. [9] investigated the use of a brominated conductive graphite fibre-epoxy unidirectional ply between non-conductive glass fibre laminates, Bernthisel and Biller [10] used an expanded graphite foil between insulating polymer sheets and Nino et al. [7] used a layer of glass fibre fabric embedded with continuous metal fibres between glass fibre laminates. Zhao et al. [11] have also explored the use of a multiwalled carbon nanotube sheet, functionalised with silver, as the thermal element bonded onto a Kevlar substructure through a vacuum-assisted resin transfer moulding process. In all cases these systems required the assembly to be effectively adhered to the aircraft surface.

Other investigations have proposed the use of piezoelectric actuators mounted on the inner skin surface to excite the structure at its natural frequencies [12] to break off the ice. Labeas et al. [13] used finite element analysis to simulate the de-icing process arising from the use of an electro-impulsive de-icing system. This technology is based on a system of inductive coils, which act as mechanical actuators, distributed along the inner leading edge surface and attached to the front spar. The impulsive loading, caused by the application of an electric current, induces mechanical vibrations which cause the ice to fracture. While the authors claim that the added weight is comparable to that of existing systems, they acknowledge potential problems with structural fatigue if this system is used regularly. The current generation of passenger aircraft (e.g. Boeing 787 and Airbus A350) have much of their primary structure made of carbon-fibre composite material. This has 
necessitated the exploration and adoption of alternative anti-icing systems to those which are commonly found on their metallic counterparts. The approach adopted on the leading edge of the Boeing 787 makes use of a molten metal spray, which forms the heating element, deposited onto a glass fibre fabric. Another glass fibre fabric is placed on top of the sprayed metal and this sub-assembly is sandwiched between two carbon fibre composite laminates of the required structural thickness before being vacuum-bagged and autoclave cured [14].

This paper presents a detailed study into the development of an integrated electro-thermal anti-icing/de-icing system particularly suited to carbon-fibre composite aerostructures which could potentially be embedded at the time of manufacture of the wing skins and trailing and leading edge sub-structures. A lightweight carbonised electro-conductive textile, from Gorix, is used as the heating element and two approaches are investigated for isolating this from the rest of the carbon-fibre structure to prevent electrical shorting. The integration of the heater into a carbon-fibre composite panel is described and a preliminary evaluation of the system in both anti-icing and de-icing modes is presented.

The relatively low through-thickness strength and fracture toughness of laminated composite structures makes them particularly susceptible to impact damage [15-18]. Tests were therefore performed to investigate the effect of low velocity impact on the performance of the heater panels and to assess the effectiveness of a modified scarf repair strategy to restore the anti-icing/de-icing capability.

\section{Manufacturing trials for the anti-icing/de-icing concept}

The approach investigated in this study makes use of a carbonised electro-conductive textile (ECT), manufactured by Gorix, which is highly drapable and easily conforms to complex geometries. It is integrated within the outer surface of the carbon-fibre laminate to provide two primary advantages. The first is that the power requirements, to reach a desired surface temperature, are less than if the electro-conductive heating element is embedded deeper within the carbon-fibre composite laminate since these laminates tend to have low transverse thermal conductivities [9]. This makes possible its use as a deicing system, which typically requires more power than for anti-icing (the power requirements for this system are investigated

later in the paper). The second advantage is the methodology developed for repairing local damage to the ECT and the supporting laminate, which can closely follow the approaches which have been developed for the structural repairs of aerostructural composites.

\subsection{Electrical connection to the ECT}


For the purposes of this investigation a $10 \mathrm{~mm}$ wide copper tape with a conductive acrylic adhesive backing (AT528-50 from Adhesive Tapes International), was used at each end of the ECT heating element. The large contact area, between the ECT and these power connectors, permits a high current flow and power density. To enhance this contact and ensure that the foil is anchored to the ECT, a pattern of holes, shown in Figure 1a, was punched using a stitching machine. To further enhance conductivity, a thin layer of silver shielding spray (RS247-4251 from RS Components) was applied to the ECT prior to bonding to the copper tape.

INSERT: Figure 1: Copper foil connectors (a) anchoring (b) heater element.

\subsection{Glass fabric insulation layer}

Initial trials showed that, without an insulating layer to separate the ECT and the structural CFRP, electrical shorting occurred and the required heating was not achieved. The use of glass fibre plies for electrical insulation has been successfully tested with other electro-thermal schemes [7, 9] and so was investigated here. Specimens (150 mm x $300 \mathrm{~mm})$ were prepared consisting of Hexcel unidirectional CFRP material system (AS4/8552) with a lay-up of $\left[+45^{\circ} /-45^{\circ} / 90^{\circ} / 0^{\circ}\right] 4 \mathrm{~s}$ yielding an overall CFRP laminate thickness of $4 \mathrm{~mm}$. On top of this was placed a layer of ECT (see Figure 1b) separated from the CFRP by layers of a tight plain weave E-glass fibre fabric (GURIT E-glass RE86P) with an areal weight of $85 \mathrm{~g} / \mathrm{m}^{2}$. In order to avoid stray carbon fibres and particles from the ECT, transferring through the glass weave layers during curing, the ECT was washed in distilled water three times before being dried and incorporated into the lay-up. A compatible 8552 resin film $\left(30 \mathrm{~g} / \mathrm{m}^{2}\right)$ was required to achieve full wetting of the glass fibre fabric and ECT. It was found that a single film layer was required per glass fibre ply and two layers for the ECT. The whole assembly was cured in an autoclave according to the CFRP manufacturer's recommended procedure.

Five panels using two plies of insulating glass fabric were produced but no heating effect could be detected, indicating that electrical shorting was still a likely cause, possibly through stray ECT fibres or sharp protrusions around the punched holes in the copper tape piercing through the glass fibres and making contact with the underlying carbon-fibres. Extensive scanning electron microscopy was conducted but no firm evidence of this could be found. The number of glass fibre insulating layers was increased to three and a new set of five panels was manufactured as shown in Figure 2a. Heating was achieved in four out of five panels indicating that while the additional glass fibre ply improved the outcome significantly, there was still an issue of reliability. While it is possible that shorting may have been the cause of the one panel failing to achieve heating, damage to the ECT and connectors during manufacture is also a possibility. Table 1 summarises the 
results of the test program for panels using glass fibre plies as the insulating material. The use of these glass fabric plies adds weight and so a lighter solution using an insulating polymer film was investigated.

INSERT: Figure 2: Heater panel assembly with (a) three glass-fibre insulating layers (b) insulating polymer film INSERT: Table 1: Heater panels with glass fibre insulation

\subsection{Polymer film insulator}

Four different insulating films, each of thickness $50 \mu \mathrm{m}$, were tested as an alternative insulating barrier to the glass fabric layers: (1) DuPont Melinex 752, a polyethylene terephthalate (PET) crystalline polymer, (2) Mitsubishi RNK PET crystalline polymer, (3) Victrex-1000 050S polyetheretherketone (PEEK) semi-crystalline polymer, and (4) Toray Plastics Lumirror 60.28 PET crystalline polymer. These were incorporated into an ECT- [+45\%-45\% $/ 90^{\circ} / 0^{\circ}$ s AS4/8552 laminate (Figure 2b). All the films worked well as an insulating medium, i.e. heating was achieved in all cases, but the ECT layer was easily peeled away with a sharp knife indicating poor adhesion to the polymer films. To improve adhesion the films were subjected to oxygen-plasma treatment which increases the activation energy by introducing functional groups in the top few $\mathrm{nm}$ of the surface of the polymer $[19,20]$. This modification enhanced the chemical binding of the matrix to the polymer. It has also been shown that there is roughening of the surface which further aids adhesion.

As indicated in Table 2, a set of samples were manufactured with one resin film between the ECT and the insulating polymer and another set with two resin films. A visual inspection of the panels revealed that better wetting of the ECT was achieved with two resin film layers. Some specimens had only one side of the polymer plasma treated while others had both sides treated. Table 2 shows the results of a qualitative inspection of the bond strength and of the heating trials. It was concluded that the Victrex film, plasma treated on both sides, gave the best overall performance. The results of the experiments summarised in Table 2 do not constitute an exhaustive set of trials and further investigation would be required to identify an optimum configuration. On the basis of the trials conducted with the $1 \mathrm{~mm}$ thick AS4/8552 CFRP laminate, the Victrex film was evaluated with another CFRP system, Hexcel IM7/8552, with a 4mm quasi-isotropic laminate. In this case, four specimens were manufactured. Examination of the panels confirmed a good bond was achieved at the CFRP/Polymer film and ECT/Polymer film interfaces and the desired heating effect was obtained.

INSERT: Table 2: Heater panels with polymer film insulation

\section{Experimental procedures for assessing anti/de-icing performance}


Facilities were not available to evaluate the performance of this anti/de-icing technology in conditions fully representative of in-service conditions. Instead, tests were conducted in an environmental chamber to gain an indication of the capability of the ECT heating system and the relative performance of panels using Victrex film and glass fibre fabric as the insulating plies. Six panels, measuring $150 \mathrm{~mm} \times 300 \mathrm{~mm}$, were used for this study. Three panels were made of AS4/8552 with a lay-up of $\left[+45 \%-45^{\circ} / 90 \% 0^{\circ}\right] 4$ s and three glass fibre insulating plies and the remainder were made of IM7/8552 with an identical lay-up and the Victrex film insulation. The change in fibre was due to material availability but their similar thermal properties [21] ensured that this change did not significantly alter the panels' thermal characteristics.

\subsection{Heating performance tests at room temperature}

A protocol was developed for determining (i) the power required as a function of temperature attained in the specimen, (ii) the heating rate and (iii) the temperature distribution over the panel. Temperature distribution was monitored using a CEDIP Jade thermal imaging camera (sampling rate of $4 \mathrm{~Hz}$ and resolution of $320 \times 240$ pixels) and K-type thermocouples spread over the surface (Figure 3). A COMARK thermocouple thermometer was used to record the temperature readings. The panel was suspended vertically by a clamp positioned at the upper long edge of the panel as indicated in Figure 3. Six panels were tested, three of each insulation type, at three different power densities obtained by the application of a current of $2 \mathrm{~A}, 3 \mathrm{~A}$ and $4 \mathrm{~A}$.

INSERT: $\quad$ Figure 3: Thermocouple (K-type) distribution

\subsection{Heating performance tests in environmental chamber}

The performance of the anti/de-icing device was tested in a Sanyo Gallenkamp FE80 environmental chamber at temperatures of $0^{\circ} \mathrm{C},-10^{\circ} \mathrm{C}$ and $-20^{\circ} \mathrm{C}$ using the same thermocouple distribution as for the tests conducted at room temperature (see Figure 4 for the experimental set-up). Specimens were left in the environmental chamber overnight, prior to testing, to ensure thermal equilibrium at each tested temperature. Again, six panels were tested, three of each insulation type, at three different power densities obtained by the application of a current of $2 \mathrm{~A}, 3 \mathrm{~A}$ and $4 \mathrm{~A}$ and the temperature readings of the thermocouples were monitored.

INSERT: Figure 4: Environmental test set-up

\subsection{Anti-icing test}


To test the effectiveness in preventing ice build-up, a water-tight dam was created around the perimeter of the panel using an Aerovac sealant tape. $100 \mathrm{ml}$ of water was placed within this dam giving a depth of approximately $4 \mathrm{~mm}$. A single thermocouple was placed at the centre of the panel and raised from the panel's surface by resting it on a small strip of sealant tape below the surface of the water.

The instrumented specimen was placed in the pre-cooled chamber and the heating current was applied to the panel. In each case an identical, but unheated, control specimen with the same water reservoir was also placed in the chamber. A constant current of approximately $2 \mathrm{~A}$ was applied to heat the panel at a chamber temperature of $-10^{\circ} \mathrm{C}$ and approximately $3 \mathrm{~A}$ was applied for a chamber temperature of $-20^{\circ} \mathrm{C}$. Temperature readings were recorded every ten minutes using the COMARK thermocouple thermometer. After one hour, the test and control panels were removed and inspected for ice build-up.

\subsection{De-icing test}

In this test, panels were tailored to hold a reservoir of water on their surface as described in Section 3.3. The environmental chamber was cooled to $-20^{\circ} \mathrm{C}$ prior to the panels being placed in the chamber. The $100 \mathrm{ml}$ of water was allowed to freeze and reach the chamber temperature. The water temperature was monitored through the submerged thermocouple in the centre of the panel. After the water reached the chamber temperature the power supply was switched on and power settings, similar to the ones used for the anti-icing tests conducted at $-20^{\circ} \mathrm{C}$, were applied. Power was maintained for one hour before the panel was removed and inspected.

\subsection{Heating performance after impact}

Four heater panels (containing a Victrex polymer insulation layer) with dimensions of $300 \mathrm{~mm} \times 150 \mathrm{~mm}$, were manufactured to assess the heater performance after impact. In this case another carbon-epoxy prepreg, Hexcel AGP280/8552 was used in which the fibre reinforcement was a five-harness satin weave fabric. The lay-up was [\{+45\%$\left.\left.45^{\circ}\right\} /\left\{90^{\circ} / 0^{\circ}\right\}\right]_{4 \mathrm{~s}}$, where the angles within a pair of curly brackets indicate the warp and weft directions of a single woven ply. Each ply had a nominal cured thickness of $0.268 \mathrm{~mm}$. Two of these panels $(\mathrm{H} 1$ and $\mathrm{H} 2)$ were impacted at three separate locations with energies $3.4 \mathrm{~J}, 5.2 \mathrm{~J}$ and $6.8 \mathrm{~J}$. The other two $(\mathrm{H} 3$ and $\mathrm{H} 4)$ were impacted with higher energies of $8.5 \mathrm{~J}, 10.2 \mathrm{~J}$ and $11.9 \mathrm{~J}$. Each panel was then connected to a power supply delivering a $2 \mathrm{~A}$ current to assess its heating performance.

\subsection{Scarf repair}

When damage of a composite structure requires a scarf repair, the heating capacity of an anti-icing/de-icing structure should also be restored as part of the repair scheme. Three panels with an identical lay-up to the impacted 
specimens in Section 3.5, had a $7 \mathrm{~mm}$ diameter hole drilled in the centre to simulate damage (Figure 5a). A circular diamond tool was used to introduce a scarfed circular cut-out with a scarf angle of $2.86^{\circ}$. Due to the width of the heater panel (150 $\mathrm{mm}$ ) and the space required for re-instating the electrical connection, the diameter of the scarfed zone was limited to an 80 $\mathrm{mm}$ diameter on the top surface as shown in Figure $5 \mathrm{~b}$. This corresponds to a depth of approximately $2 \mathrm{~mm}$. For clarity, what is not shown in this and subsequent figures is the additional scarf repair that was undertaken on the other side of each specimen.

INSERT: Figure 5: Scarf repair stages for upper surface

To avoid electrical contact between the CFRP patch to be inserted, and the existing ECT, a 12-17 mm wide ring of insulating film around the periphery of the scarf was exposed by carefully grit-blasting the ECT ring at low pressure as shown in Figure $5 \mathrm{~b}$. The ECT region around the scarf was also lightly grit-blasted over a width of around $10 \mathrm{~mm}$ to roughen the surface for subsequent bonding operations as described later. A double layer of 8552 resin film was placed on the degreased scarf area prior to introducing a pre-cured CFRP patch which had a lay-up matching the parent material (Figure 5c). A plasma-treated circular insulation film was next placed over the patch followed by another double layer of resin film.

The next step involved the introduction of the ECT circular patch required to restore the uniform heating performance of the panel. To ensure good electrical contact between the exposed ECT, which was lightly grit-blasted, and the new circular ECT patch, a silver-loaded adhesive (a two component high conductive adhesive system, CHOBOND 58429 from Chomerics) was used. To avoid creating a low resistance path around the repair the adhesive was placed in roughly circular patches of approximately $3 \mathrm{~mm}$ diameter at $9-10 \mathrm{~mm}$ intervals along the midline of the exposed ECT ring before the placement of the ECT patch. To ensure adequate bonding between the 'old' ECT and the introduced patch, a doublelayered resin film ring was placed on top of the overlapping ECT region as shown in Figure $5 \mathrm{~d}$. The whole assembly was vacuum-bagged and cured in an autoclave following the manufacturer's cure cycle for the resin film and a representative repaired panel is shown in Figure 5e. A heating trial was then conducted on the panel to assess the effects of the repair.

\section{Experimental results}

\subsection{Heating performance tests at room temperature}

At a constant current of $2 \mathrm{~A}$, the thermal images in Figure 6 were obtained from the thermal imaging camera for a panel with glass insulation and a panel with Victrex film insulation. The images shown were recorded at 90 seconds after the start of heating, at three minutes, at 20 minutes when the temperature had stabilised and at three minutes after the power 
supply has been switched off. For this same current, the heat flux (power density) was $370 \mathrm{~W} / \mathrm{m}^{2}$ for the film-insulated panel and $280 \mathrm{~W} / \mathrm{m}^{2}$ for the glass fibre insulated panel, i.e. the former had a higher electrical resistance. The images show that the panel with the Victrex film insulation had a higher heating rate and achieved a higher stable temperature than the panel with the glass fibre fabric insulation - as expected from the higher power density and lower heat capacity of the Victrex panel. The last two images (Figures 6g-6h) suggest a lower temperature dissipation rate for the glass fibre insulated panel which may be due to the greater thermal mass of this panel. Figure 8 shows the change in average thermocouple temperature as a function of time and confirms the higher heating rate and stabilised temperature achieved in the Victrex film-insulated panel.

INSERT: Figure 6: Thermal imaging of tests performed at room temperature at a constant current of $2 \mathrm{~A}$.

INSERT: Figure 7: Heating rates at a constant current of $2 \mathrm{~A}$

Figure 8 shows the achieved stable temperature increase plotted against power density for the glass and film insulated configurations from the constant current tests at $2 \mathrm{~A}, 3 \mathrm{~A}$ and $4 \mathrm{~A}$. Each test was repeated three times, allowing the specimen to cool to room temperature between tests. The curve fit suggests that for a given power density the stabilised temperature achieved is the same for the two insulation types i.e. both types of panel are equally efficient at converting the input electrical energy into heat. (This assumes that the energy loss from the panels, at a given temperature, is the same for both types of insulated panel.)

INSERT: $\quad$ Figure 8: Change in temperature as a function of power density at room temperature

\subsection{Heating performance tests in environmental chamber}

Figure 9 shows the stabilised temperature change achieved as a function of power density for a Victrex filminsulated panel in the tests conducted in the environmental chambers at different chamber temperatures. The curves fitted to each of the three data sets (one set for each of the chamber temperatures of $0^{\circ} \mathrm{C},-10^{\circ} \mathrm{C}$ and $-20^{\circ} \mathrm{C}$ ) are in good agreement. This indicates that for a given temperature increase, the rate of energy extraction by the environmental chamber is constant. Figure 9 also includes a plot of the temperature change achieved in the room temperature tests of the Victrex panel. It can be seen that to achieve the same temperature increase, a greater power density was required for the tests conducted in the environmental chamber i.e. the energy extraction rate in the environmental chamber is greater than the rate of energy loss in the tests conducted at room temperature in the open laboratory.

The environmental data shown in Figure 9 is only for one set of readings for each applied current. As stated earlier, these tests were repeated three times and the same test programme was also conducted on the glass fabric 
insulated panels. The plot in Figure 10, of all the data for both panel configurations, shows that the power density required to achieve a given temperature change in the environmental chamber was similar for the glass and film insulated panels (as observed earlier in Figure 8 for the tests conducted in an open laboratory at room temperature).

INSERT: $\quad$ Figure 9: Change in temperature as a function of power density at different ambient temperatures for film insulated panels.

INSERT: $\quad$ Figure 10: Change in temperature as a function of power density at different ambient temperatures conducted in the environmental chamber at temperatures of $0^{\circ} \mathrm{C},-10^{\circ} \mathrm{C},-20^{\circ} \mathrm{C}$.

\subsection{Anti-icing tests}

Table 3 and Table 4 list the results of the tests conducted on six panels, three with the glass fibre insulation (Table 3) and three with the polymer film insulation (Table 4). In all cases the water reservoir on unheated control samples was totally frozen. At $-10^{\circ} \mathrm{C}$ and under similar power density, at which the glass fibre insulated panels drew more current than the polymer film insulated ones, it was noted that the former struggled to prevent some build-up of ice. The thermocouple readings on a glass-fibre insulated panel (Panel $1 \mathrm{G}$ ) at a power density of $430 \mathrm{~W} / \mathrm{m}^{2}$ showed that the water temperature stabilised at $0^{\circ} \mathrm{C}$ after 40 minutes in the chamber and some ice was observed at one corner. Increasing the power density by $17 \%$, to $505 \mathrm{~W} / \mathrm{m}^{2}$, while maintaining the same chamber temperature of $-10^{\circ} \mathrm{C}$, enabled Panel $1 \mathrm{G}$ to achieve a higher stabilised temperature of $4^{\circ} \mathrm{C}$. Panel $2 \mathrm{G}$, at the same chamber temperature and at the same raised power density, struggled to prevent the water from freezing. The power density for Panel $3 \mathrm{G}$ was further increased to $570 \mathrm{~W} / \mathrm{m}^{2}$, representing a $33 \%$ increase over the initial power density, and the stabilised water temperature was $7^{\circ} \mathrm{C}$. In contrast, the film insulated panels were more effective with no evidence of ice build-up at a power density of $420-440 \mathrm{~W} / \mathrm{m}^{2}$ for a chamber temperature of $10^{\circ} \mathrm{C}$, resulting in final water temperatures above freezing.

INSERT: Table 3: Anti-icing test results for glass-fibre insulated panels

INSERT: Table 4: Anti-icing test results for polymer film insulated panels

At a chamber temperature of $-20^{\circ} \mathrm{C}$ and a current of $3.8 \mathrm{~A}$ for each glass fibre insulated panel $\left(854-863 \mathrm{~W} / \mathrm{m}^{2}\right)$, a small area of ice build-up was observed in the corner of two of the three panels. No ice build-up was observed on the film insulated panels at a power density of $838 \mathrm{~W} / \mathrm{m}^{2}$ and $3.2 \mathrm{~A}$. Figure 11 shows a plot of the temperature rise achieved as a function of power density and indicates that the power density requirements, to achieve a target temperature change to prevent ice build-up, were similar for both glass and film insulated panels. This is consistent with the results reported, in Section 4.2, for the tests conducted with dry panels in an environmental chamber. 
INSERT: $\quad$ Figure 11 : Change in temperature as a function of power density for anti-icing studies.

\subsection{De-icing tests}

Table 5 lists the results of the de-icing tests conducted on three panels with glass fibre insulation and Table 6 gives the results for three panels with Victrex polymer film insulation. The tests were conducted at a chamber temperature of $-20{ }^{\circ} \mathrm{C}$ with each panel allowed to reach the chamber temperature prior to supplying power to the panel. At 60 minutes after the start of heating, the panel was removed and inspected. As expected, the water reservoir on unheated control samples was totally frozen in all cases.

Tables 5 and 6 show that the film insulated panels required less energy than the glass insulated panels to achieve significant de-icing after 60 minutes. The glass fibre insulated panels, at an average power density of $933 \mathrm{~W} / \mathrm{m}^{2}$, achieved a corresponding average temperature of $4.3^{\circ} \mathrm{C}$ while the film-insulated panels achieved an average temperature of $5.0^{\circ} \mathrm{C}$ at an average power density of $833 \mathrm{~W} / \mathrm{m}^{2}$. A considerable amount of ice remained on the glass fibre insulated panel surfaces in contrast to the film insulated ones where only small areas of ice remained as shown in Figure 12. The glass insulated panels could be expected to take longer to fully heat up due to the greater thermal mass, as observed in the room temperature heating trials discussed in section 4.1, and this may account for the better de-icing performance observed in the film-insulated panels.

INSERT: Table 5: De-icing test results for glass fibre insulated panels

INSERT: Table 6: De-icing test results for film insulated panels

INSERT: Figure 12: (a) Film insulated panel after de-icing (b) control panel

\subsection{Heater performance tests after impact}

Two of these panels $(\mathrm{H} 1$ and $\mathrm{H} 2)$ were impacted at three locations, indicated by the $\mathrm{C}$-scan images in Figure 13, with energies 3.4J, $5.2 \mathrm{~J}$ and $6.8 \mathrm{~J}$. The other two $(\mathrm{H} 3$ and $\mathrm{H} 4)$ were impacted with higher energies of $8.5 \mathrm{~J}, 10.2 \mathrm{~J}$ and 11.9

J. Each panel was connected to a power supply delivering a $2 \mathrm{~A}$ current to assess its heating performance. Figure 14 shows the results of one such panel $(\mathrm{H} 3)$ before and after impact. As is evident, the heating performance was not significantly affected with both cases showing a fairly uniform heating distribution. Two spots of slightly higher temperature may be deduced after heating for 1.5 minutes, corresponding to impact locations with higher impact energies of $10.2 \mathrm{~J}$ and $11.9 \mathrm{~J}$. These spots were not noticeable once the temperature had stabilised. 
INSERT: Figure 13: C-scans of polymer film insulated panels made from five-harness satin weave prepreg (AGP280/8552) with multiple impacts. The arrows indicate direction of increasing impact energy.

INSERT: Figure 14: Thermal imaging of impacted panel

\subsection{Heating performance of the repaired heater panel}

The heating performances of one of the panels (R2) in its pristine state and after the repair are shown in Figure 21. It is observed that heating has been restored throughout the repaired panel although there is a slightly higher degree of nonuniformity in the heat distribution throughout the heating cycle, particularly where the new ECT patch overlaps the rest of the ECT layer.

INSERT: Figure 15: Thermal imaging of repaired panel

\section{Discussion}

The testing protocols in this paper were used to demonstrate the feasibility of the anti-icing/de-icing capability of the proposed technology. In general, they do not resemble the actual rigorous testing regime which would be required for aircraft certification although, to some extent, they are informed by them.

The power density/heat flux requirements of an anti-icing / de-icing system will be dependent on the temperature ramp-up rates, the change in temperature sought and the convective heat exchange with the air flow which will be a function of the particular ambient conditions. The test cases presented as part of a numerical study by Harireche et al. [4] give an indication of the heat losses due to convective cooling with the ambient air. A heat transfer coefficient of $150 \mathrm{~W} / \mathrm{m}^{2}{ }^{\circ} \mathrm{C}$ was used in the modelling of an anti-icing device with a power supply which ranged from 10 to $30 \mathrm{~kW} / \mathrm{m}^{2}$. A higher heat transfer coefficient of $450 \mathrm{~W} / \mathrm{m}^{2}{ }^{\circ} \mathrm{C}$, for a multi-element system which is cycled successively every ten seconds, was used for modelling de-icing with a power source ranging from a continuous $5 \mathrm{~kW} / \mathrm{m}^{2}$ to $32 \mathrm{~kW} / \mathrm{m}^{2}$. With reference to Figure 10 and assuming steady state conditions, the heat transfer coefficient achieved in the test set-up used here is approximately $40 \mathrm{~W} / \mathrm{m}^{2}{ }^{\circ} \mathrm{C}$ which is much lower than the figures used by Harireche et al. [4]. Further testing will be required to assess the performance of the heater system at higher heat transfer coefficients.

In Tables 3-6 it is observed that the energy requirements to achieve effective anti-icing were lower than those for de-icing in a 60 minute period. The glass fibre insulated panels, in the anti-icing tests, struggled to prevent surface water 
from freezing at lower energy densities when compared to the equivalent film-insulated devices. The film insulated panels also demonstrated better performance for de-icing at a chamber temperature of $-20^{\circ} \mathrm{C}$ for which, at a power density of between 815 and $853 \mathrm{~W} / \mathrm{m}^{2}$, ice formed prior to heating was mostly melted. For equivalent and higher power densities, the glass fibre insulated panels still had between half and two thirds of the surface still covered in ice. These differences in thermal performance between the glass- and film-insulated panels are due to the greater thermal mass of the glassinsulated panels and the resulting longer duration needed to reach steady-state.

Under higher impact loads, there was evidence of a slightly raised temperature at the impacted regions. This is most likely due to localised damage, which is mostly delamination at the impact loads considered, giving rise to changes in the heat diffusion rates at these sites. The scarf repair scheme proposed in this work demonstrated the re-establishment of heating throughout the panel. The observed small non-uniformity in the heat distribution, particularly around the contact region between the new ECT patch and the rest of the ECT, may be mitigated by optimising the pattern of the silver-loaded adhesive in this contact region.

\section{Concluding Remarks}

The anti-icing/de-icing performance of a carbon-based electro-conductive textile (ECT) integrated in a carbon fibre composite laminate has been evaluated. Woven glass fibre plies and PEEK/PET polymer films were investigated as a means of preventing electrical short-circuiting between the ECT and the structural carbon fibres. The multiple layers of glass fabric were required to achieve a satisfactory level of insulation, adding weight to the structure. A plasma-treated $50 \mu \mathrm{m}$ thick Victrex PEEK film was found to provide good insulation and a satisfactory level of bonding to the resin-infused ECT and structural carbon-fibre surfaces.

The heating tests for both glass fibre and film insulated devices showed that the film-insulated panels yielded better heating rates for both anti-icing and de-icing. Further testing with an environmental chamber which can achieve higher, more realistic heat transfer coefficients is required to establish the full potential of the ECT heating system for control of icing on aircraft structures. It is believed that with typical on-board power capacity such a heating system could enable the coverage of large surface areas which offers the possibility for smaller category commuter aircraft to have comprehensive on-board anti-icing and de-icing capability thus avoiding the application of de-icing fluids on stationary aircraft.

These devices were also assessed for their damage tolerance. Their heating performance was shown not to be compromised when subjected a range of impact energies that did not breach the ECT to the extent of causing electrical 
shorting. For more substantial damage, a modified scarf repair strategy was shown to restore the heating capacity of the panels.

\section{ACKNOWLEDGEMENT}

The authors would like to express their gratitude to Mr Matthew Taylor and Mr Matthieu Gimat, students of Imperial College London, who conducted some of the experimental investigations reported in this paper. The authors gratefully acknowledge the financial support from the DTI (TP/4/MHP/6///22195) and the first author would also like to acknowledge the financial support of Bombardier and the Royal Academy of Engineering.

\section{REFERENCES}

1. Lynch, F.T. and A. Khodadoust, Effects of ice accretions on aircraft aerodynamics. Progress in Aerospace Sciences, 2001. 37(8): p. 669-767.

2. Broeren, A.P., M.B. Bragg, H.E. Addy Jr, S. Lee, F. Moens, and D. Guffond, Effect of high-fidelity ice-accretion simulations on full-scale airfoil performance. Journal of Aircraft, 2010. 47(1): p. 240-254.

3. Fossati, M., R.A. Khurram, and W.G. Habashi, An ALE mesh movement scheme for long-term in-flight ice accretion. International Journal for Numerical Methods in Fluids, 2012. 68(8): p. 958-976.

4. Harireche, O., P. Verdin, C.P. Thompson, and D.W. Hammond, Explicit finite volume modeling of aircraft anti-icing and de-icing. Journal of Aircraft, 2008. 45(6): p. 1924-1936.

5. Sun, Z., C. Hu, and C. Zhu, Ice accretion prediction for single airfoil and multi-element airfoil. Applied Mechanics and Materials, 2012. 138-189: p. 140-145.

6. Thomas, J.P., R.P. Cassoni, and C.D. MacArthur, Aircraft anti-icing and de-icing techniques and modeling. Journal of Aircraft, 1996. 41: p. 1291-1297.

7. Nino, G.F., H.E.N. Bersee, A. Beukers, and T.J. Ahmed, Erosion of Reinforced Thermoplastic Composite Structures (AIAA2008-1909), in 49th AIAA/ASME/ASCE/AHS/ASC Structures, Structural Dynamics and Materials Conference,2008, AIAA: Schaumburg, IL.

8. McCormick, C. Infrared Deicing: Giving glycol a run for its money. 2007 [cited 2014; Available from: $\mathrm{http}: / /$ www. wingsmagazine.com/content/view/1325/38.

9. Hung, C.-C., M.E. Dillehay, and M. Stahl, A Heater made from Graphite composite material for potential deicing application. NASA Technical Memorandum 88888, (NASA-TM-88888), 1987.

10. Bernthisel, J. and B. Biller, New Thin Film Heating Elements for Rapid, Even Heating of Large Surface Areas. Appliance, 2003. 60(10): p. 41-43.

11. Zhao, W., M. Li, Z. Zhang, and H.X. Peng, Carbon Nanotube-based composites film heater for de-icing applications, in 14th European Conference on Composite Materials7-10 June 2010: Budapest, Hungary.

12. Struggl, S., J. Korak, and C. Feyrer. A basic approach for wing leading deicing by smart structures. in Proceedings of SPIE - The International Society for Optical Engineering, v 7981. 2011. Sensors and Smart Structures Technologies for Civil, Mechanical, and Aerospace Systems

13. Labeas, G., Simulation of the electroimpulse de-icing process of aircraft wings. Journal of Aircraft, 2006. 43(6): p. 1876-1885.

14. Chung, Y.-W., De-icing system chosen for boeing 787. Journal of Failure Analysis and Prevention, 2005. 5(2): p. 36.

15. Donadon, M.V., L. lannucci, B.G. Falzon, J.M. Hodgkinson, and S.F.M. de Almeida, A progressive failure model for composite laminates subjected to low velocity impact damage. Computers and Structures, 2008. 86(11-12): $\mathrm{p}$. 1232-1252.

16. Faggiani, A. and B.G. Falzon, Prediciting low-velocity impact damage on a stiffened composite panel. Composites, Part A: Applied Science and Manufacturing, 2010. 41: p. 737-749.

17. Falzon, B.G., Impact damage and repair of composite structures. The Aeronautical journal, 2009. 113(1145): p. 431-445. 
18. Heimbs, S., S. Heller, P. Middendorf, F. Hähnel, and J. Weiße, Low velocity impact on CFRP plates with compressive preload: Test and modelling. International Journal of Impact Engineering, 2009. 36(10-11): p. $1182-$ 1193.

19. Junkar, I., A. Vesel, U. Cvelbar, M. Mozetï̈, and S. Strnad, Influence of oxygen and nitrogen plasma treatment on polyethylene terephthalate (PET) polymers. Vacuum, 2009. 84(1): p. 83-85.

20. Vesel, A., I. Junkar, U. Cvelbar, J. Kovac, and M. Mozetic, Surface modification of polyester by oxygen- and nitrogen-plasma treatment. Surface and Interface Analysis, 2008. 40(11): p. 1444-1453.

21. Daniel, I.M. and O. Ishai, Engineering Mechanics of Composite Materials. 2nd ed. 2006, New York: Oxford University Press. 


\section{Figure captions}

Figure 1: Copper foil connectors (a) anchoring (b) heater element.

Figure 2: Heater panel assembly with (a) three glass-fibre insulating layers (b) insulating polymer film. Figure 3: Thermocouple (K-type) distribution.

Figure 4: Environmental test set-up.

Figure 5 Scarf repair stages for upper surface.

Figure 6: Thermal imaging of tests performed at room temperature at a constant current of $2 \mathrm{~A}$.

Figure 7: Temperature rise at a constant current of $2 \mathrm{~A}$.

Figure 8: Change in temperature as a function of power density at room temperature.

Figure 9: Change in temperature as a function of power density at different ambient temperatures for film insulated panels

Figure 10: Change in temperature as a function of power density at different ambient temperatures conducted in the environmental chamber at temperatures of $0^{\circ} \mathrm{C},-10^{\circ} \mathrm{C},-20^{\circ} \mathrm{C}$.

Figure 11: Change in temperature as a function of power density for anti-icing studies.

Figure 12: (a) Film insulated panel after de-icing (b) control panel.

Figure 13: C-scans of polymer film insulated panels made from five-harness satin weave prepreg (AGP280/8552) with multiple impacts. The arrows indicate direction of increasing impact energy.

Figure 14: Thermal imaging before and after impact of ECT panel.

Figure 15: Thermal imaging of repaired panel

\section{Table captions}

Table 1: Heater panels with glass-fibre insulation.

Table 2: Heater panels with polymer film insulation.

Table 3: Anti-icing test results for glass-fibre insulated panels.

Table 4: Anti-icing test results for Victex polymer film insulated panels.

Table 5: De-icing test results for glass-fibre insulated panels.

Table 6: De-icing test results for film insulated panels. 


\section{Figures}

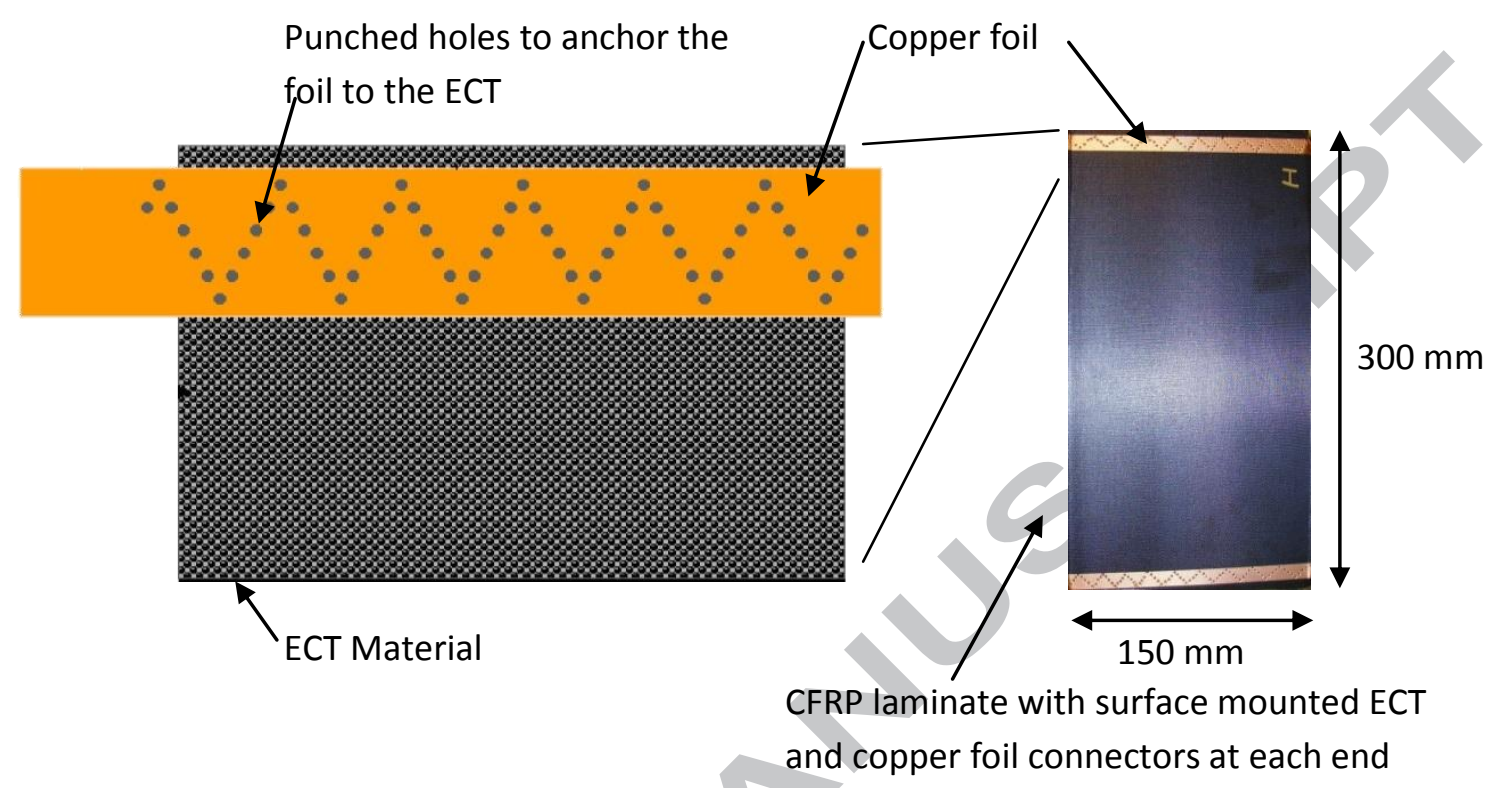

(a)

(b)

Figure 1: Copper foil connectors (a) anchoring (b) heater element.
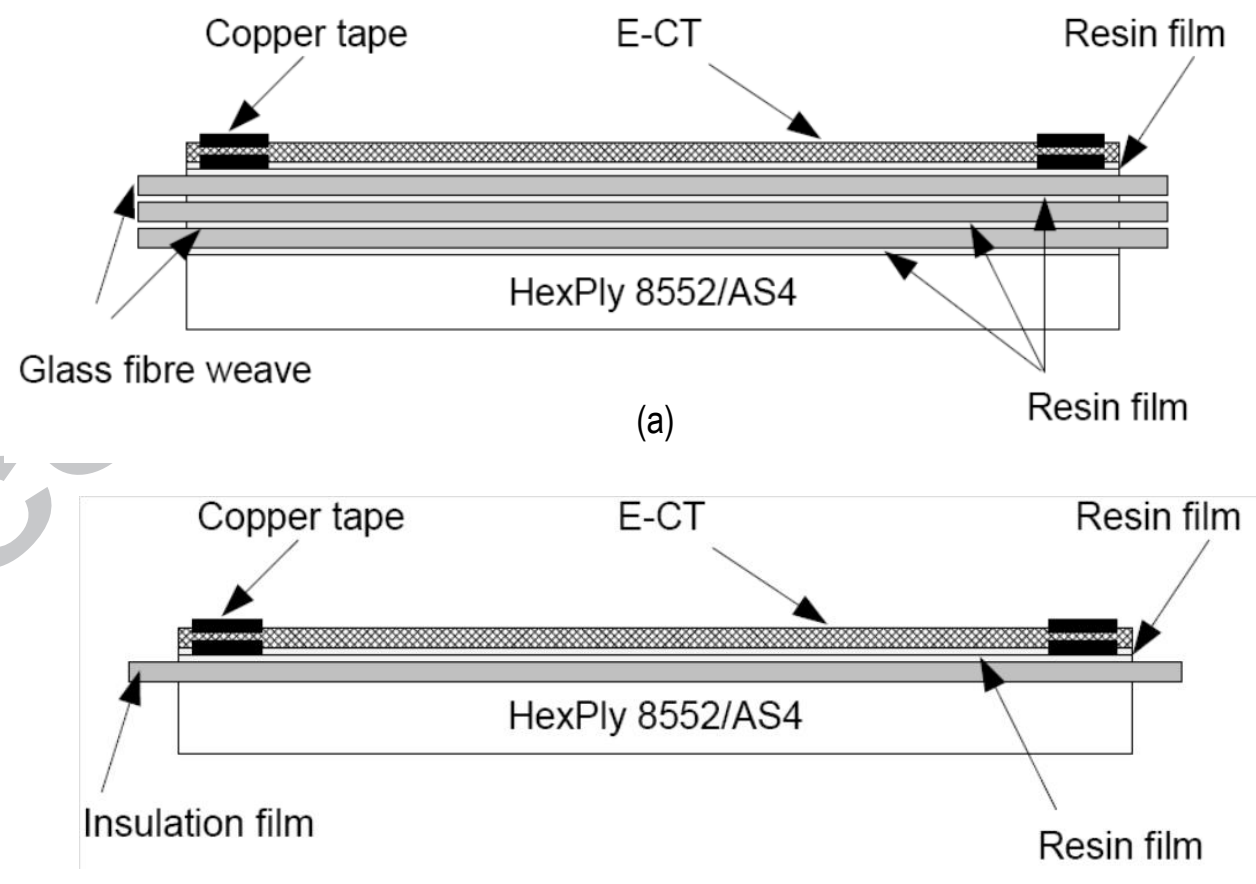

(b)

Figure 2: Heater panel assembly with (a) three glass-fibre insulating layers (b) insulating polymer film. 


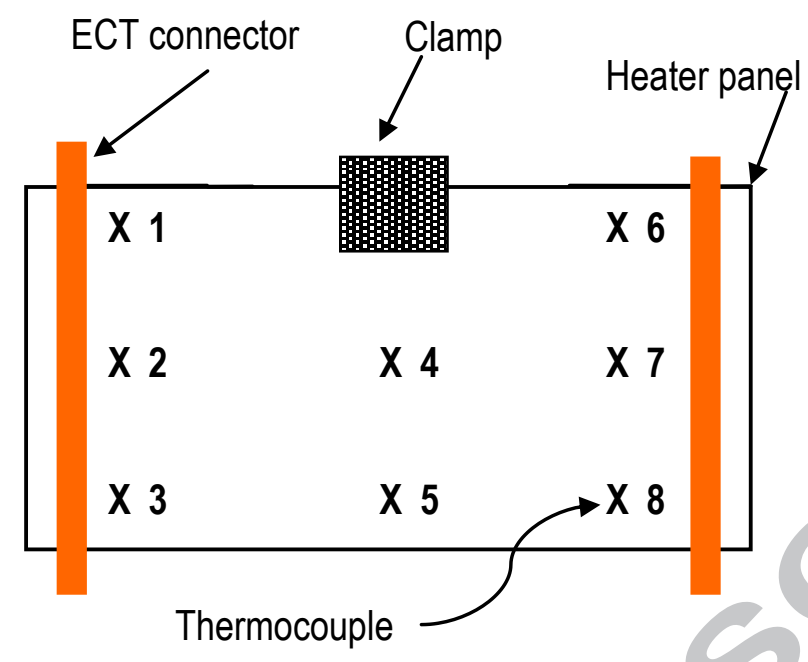

Figure 3: Thermocouple (K-type) distribution.

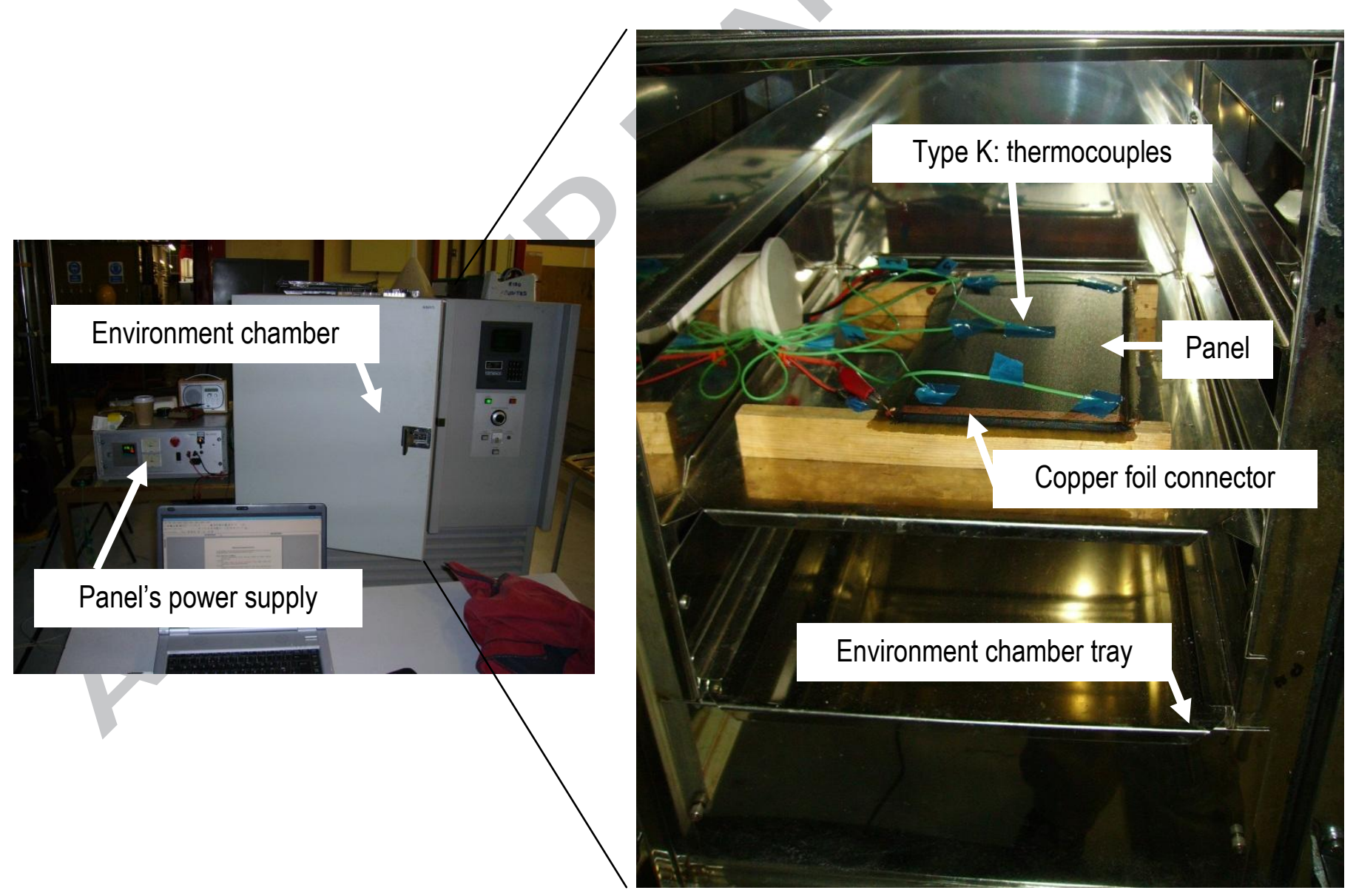

Figure 4: Environmental test set-up. 
insulating film<smiles>C=CC(=C)Br</smiles>

a)

copper tape

ECT infused with cured resin

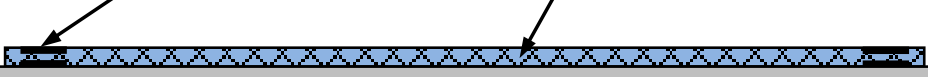

cured AGP280/8552

b)

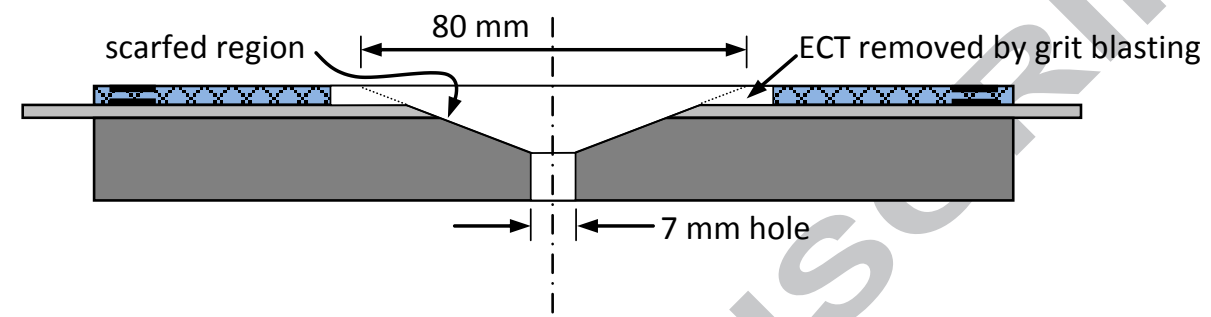

c)

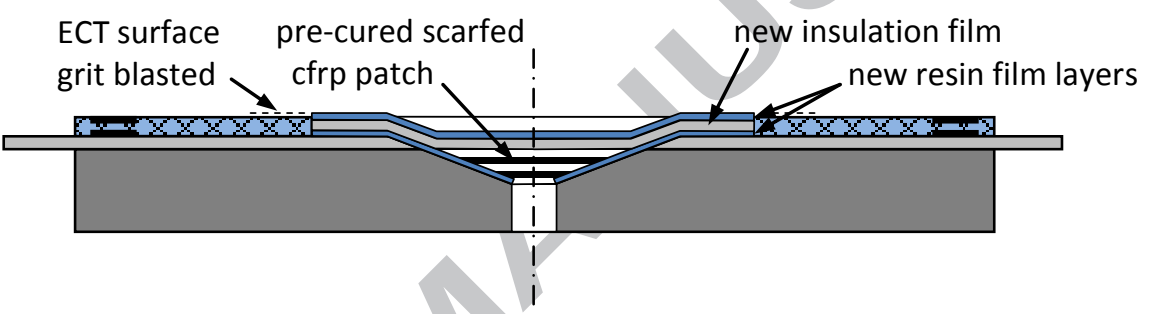

d)

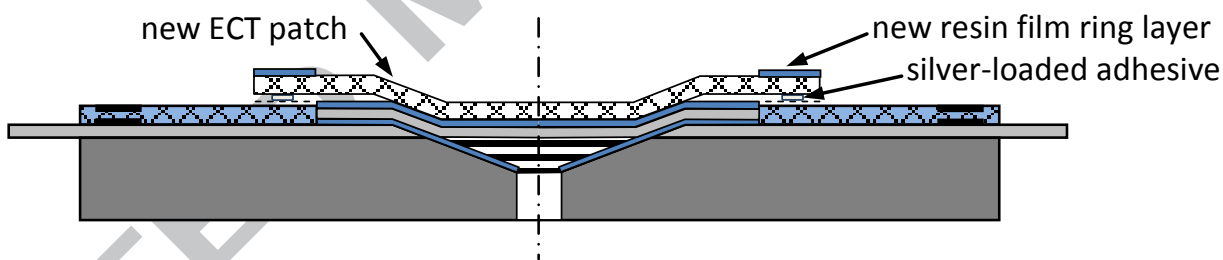

e)

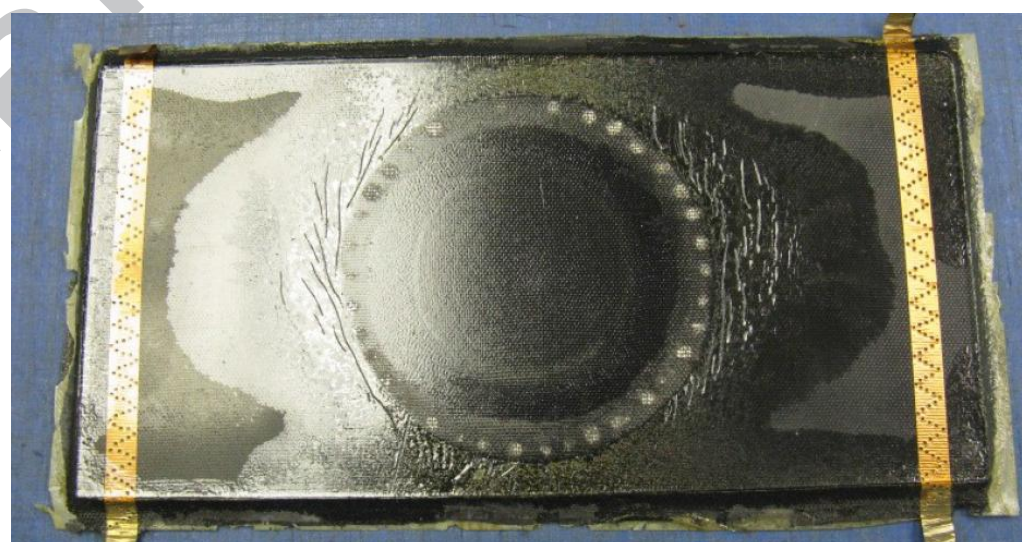

Figure 5 Scarf repair stages for upper surface. 


\section{GLASS-FIBRE INSULATION}

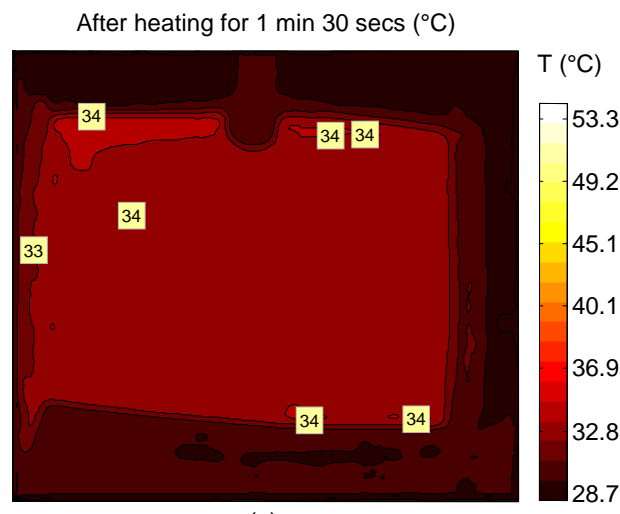

(a)

After heating for $3 \mathrm{mins}\left({ }^{\circ} \mathrm{C}\right)$

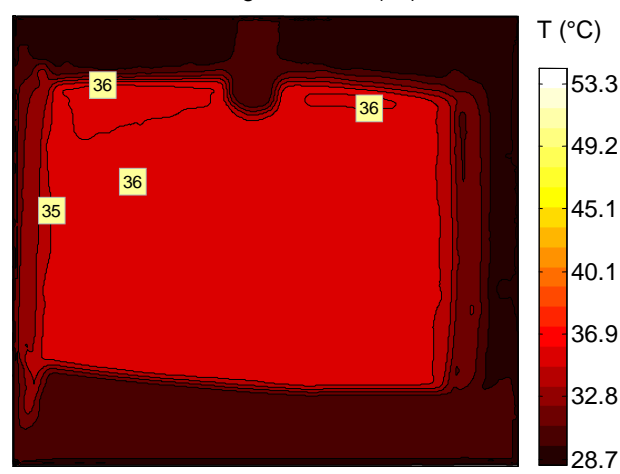

(c)

After heating for 20 mins - Stable $\left({ }^{\circ} \mathrm{C}\right)$

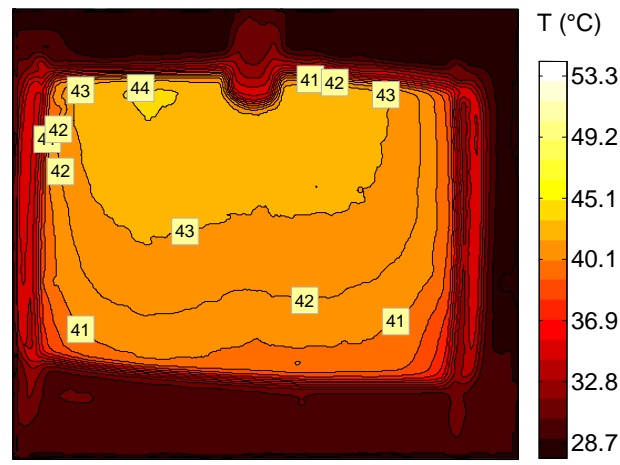

(e)

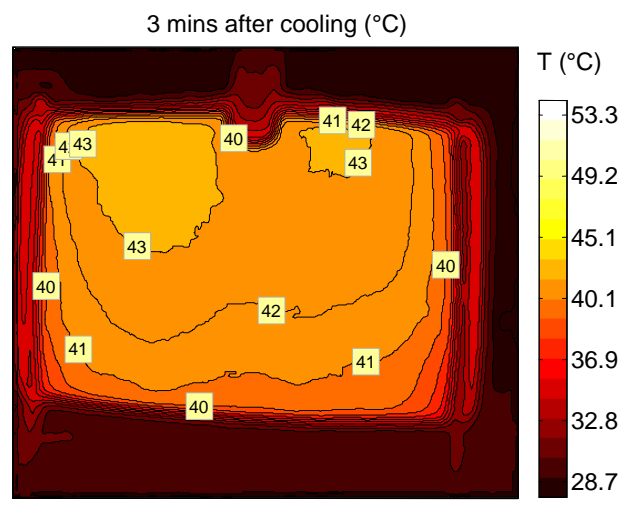

(g)
POLYMER FILM INSULATION

After heating for $1 \min 30 \operatorname{secs}\left({ }^{\circ} \mathrm{C}\right)$

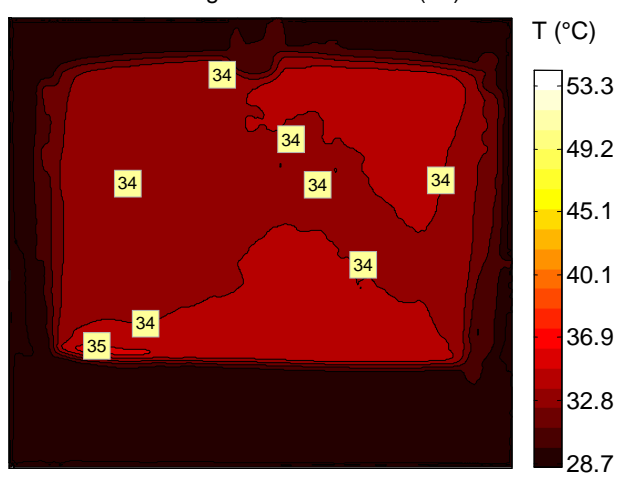

(b)

After heating for 3 mins $\left({ }^{\circ} \mathrm{C}\right)$

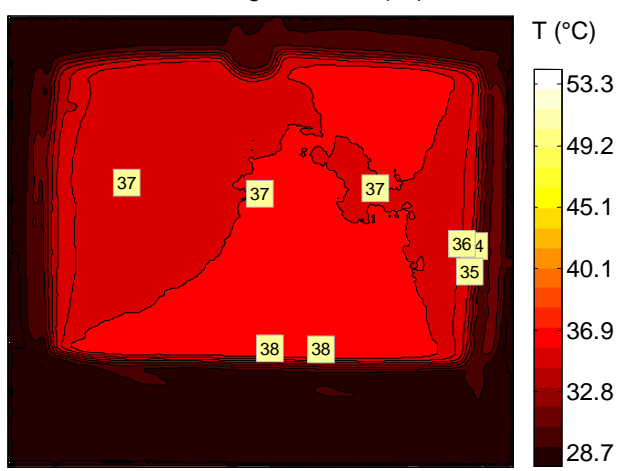

(d)

After heating for 20 mins - Stable $\left({ }^{\circ} \mathrm{C}\right)$

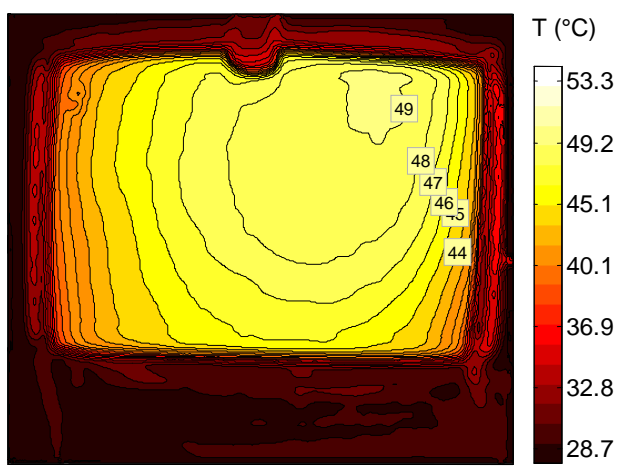

(f)

3 mins after cooling $\left({ }^{\circ} \mathrm{C}\right)$

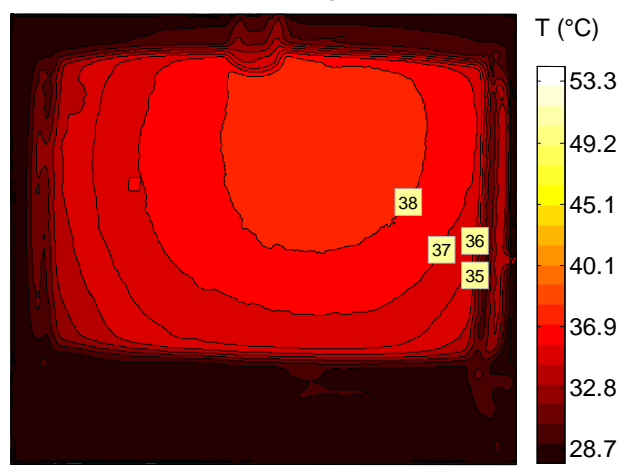

(h)

Figure 6: Thermal imaging of tests performed at room temperature at a constant current of 2A. 


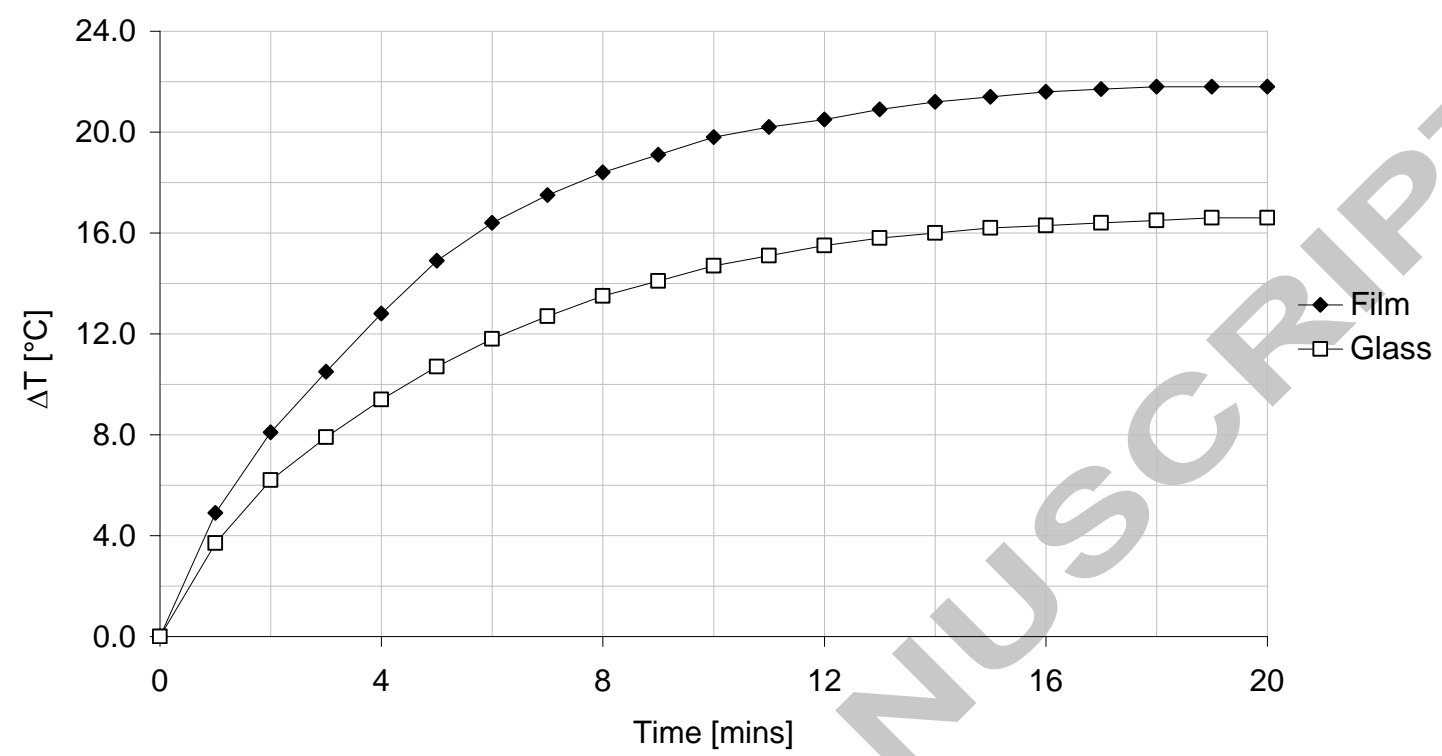

Figure 7: Temperature rise at a constant current of 2A.

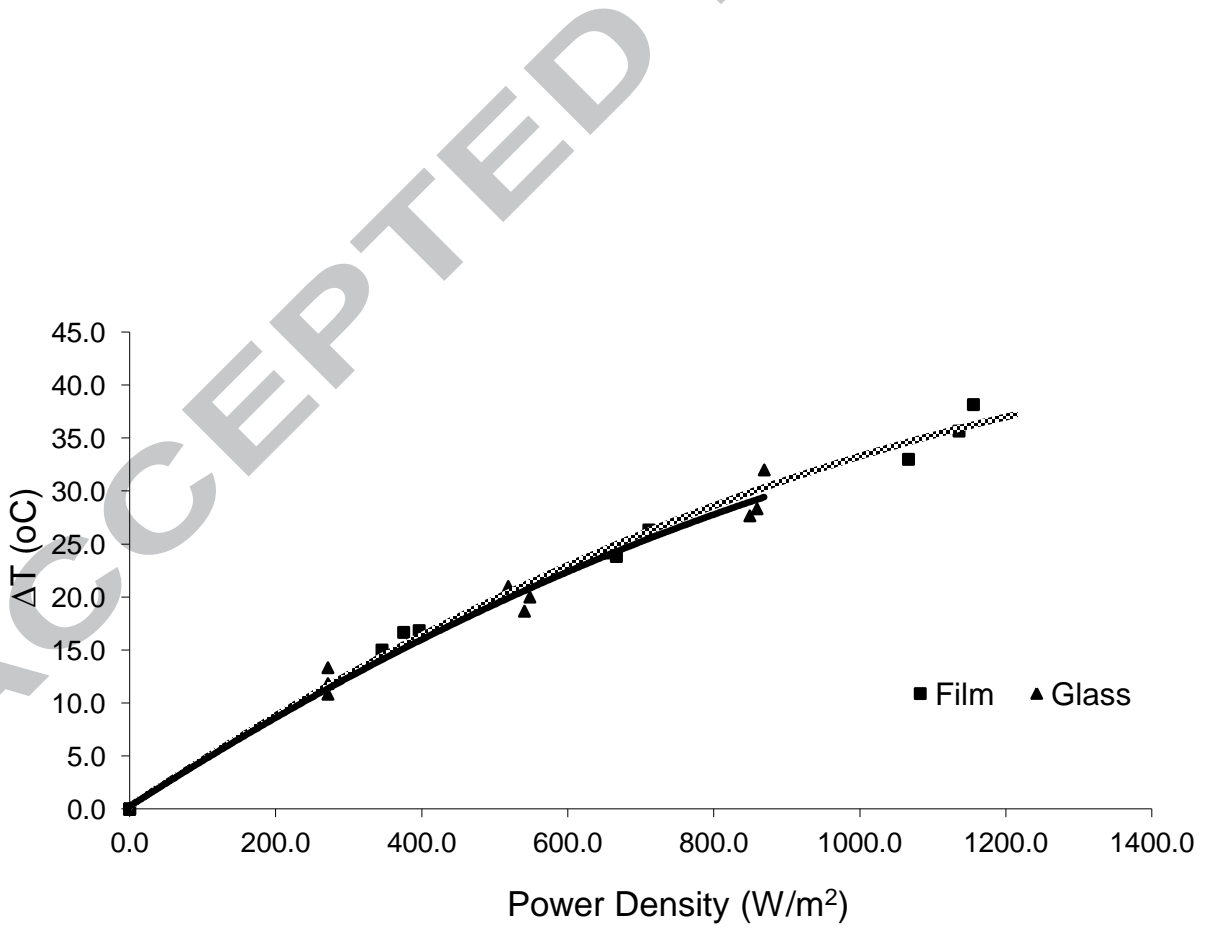

Figure 8: Change in temperature as a function of power density at room temperature. 


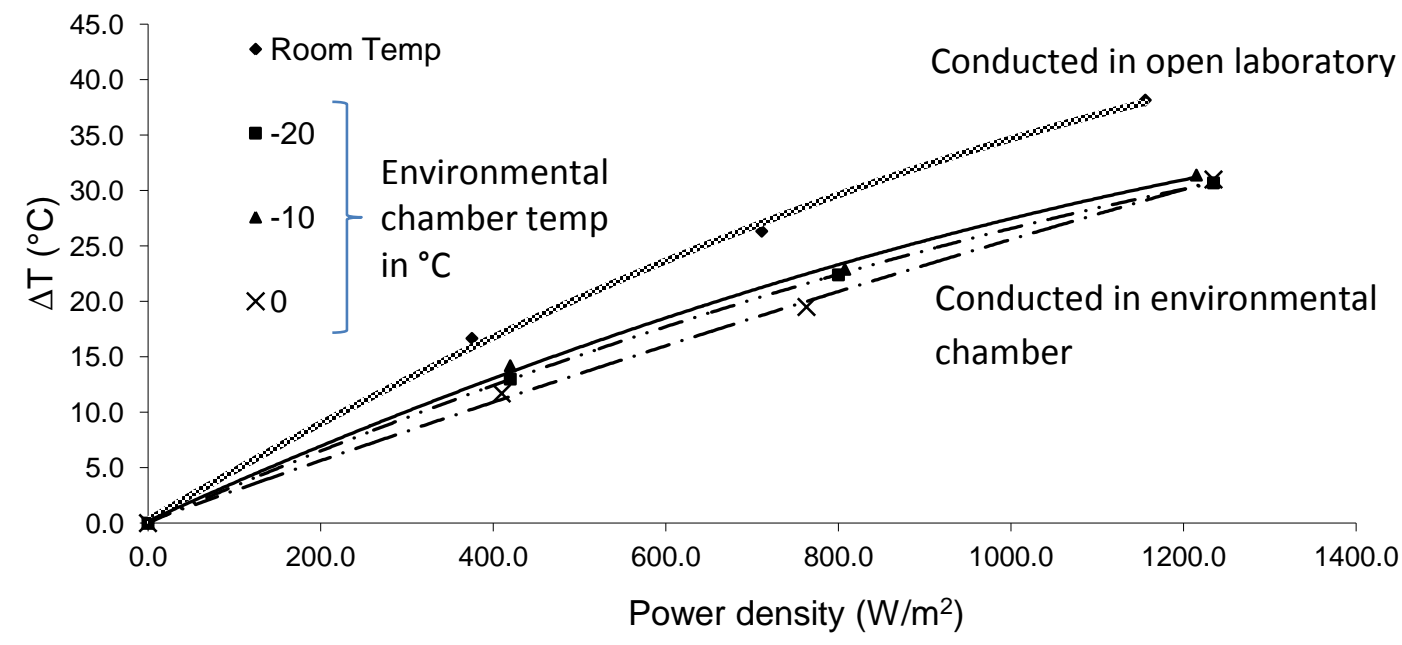

Figure 9: Change in temperature as a function of power density at different ambient temperatures for film insulated panels.

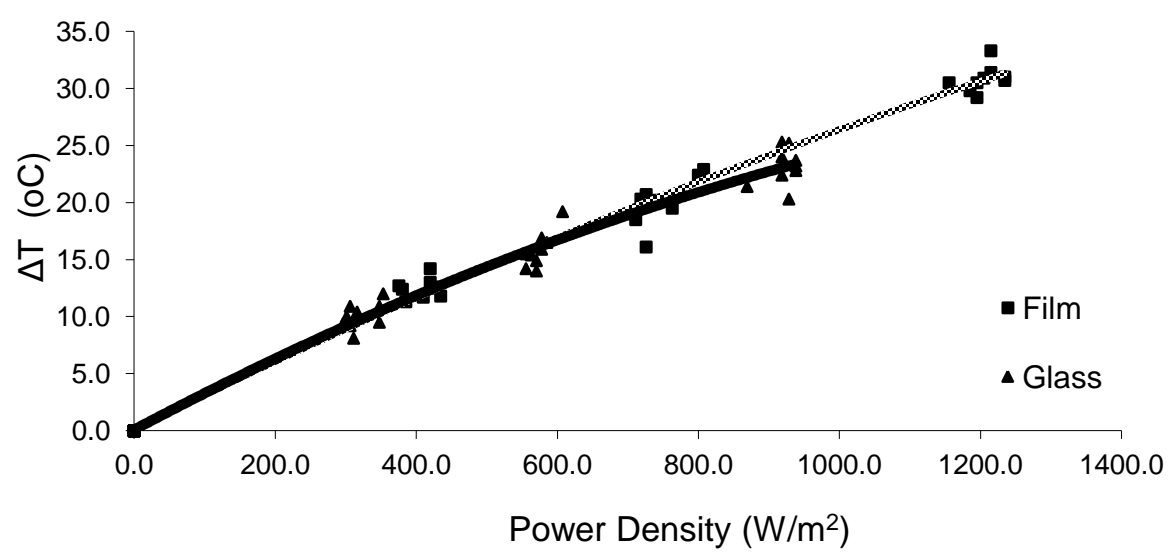

Figure 10: Change in temperature as a function of power density at different ambient temperatures conducted in the environmental chamber at temperatures of $0^{\circ} \mathrm{C},-10^{\circ} \mathrm{C},-20^{\circ} \mathrm{C}$. 


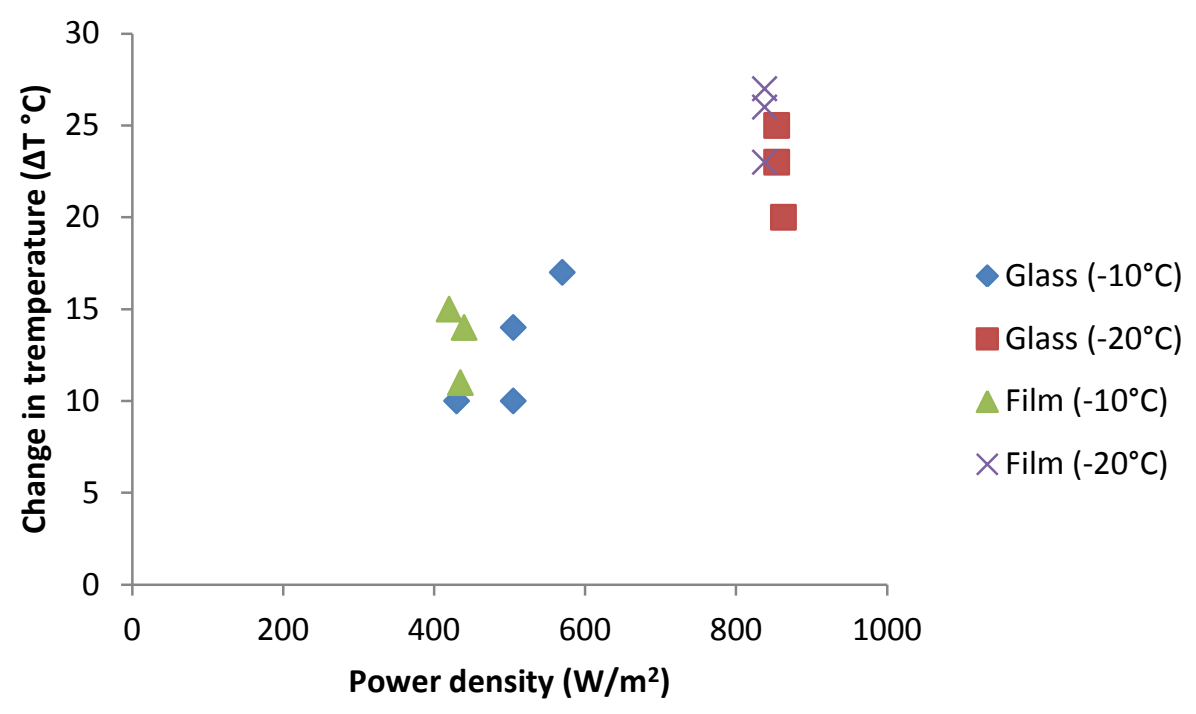

Figure 11: Change in temperature as a function of power density for anti-icing studies.

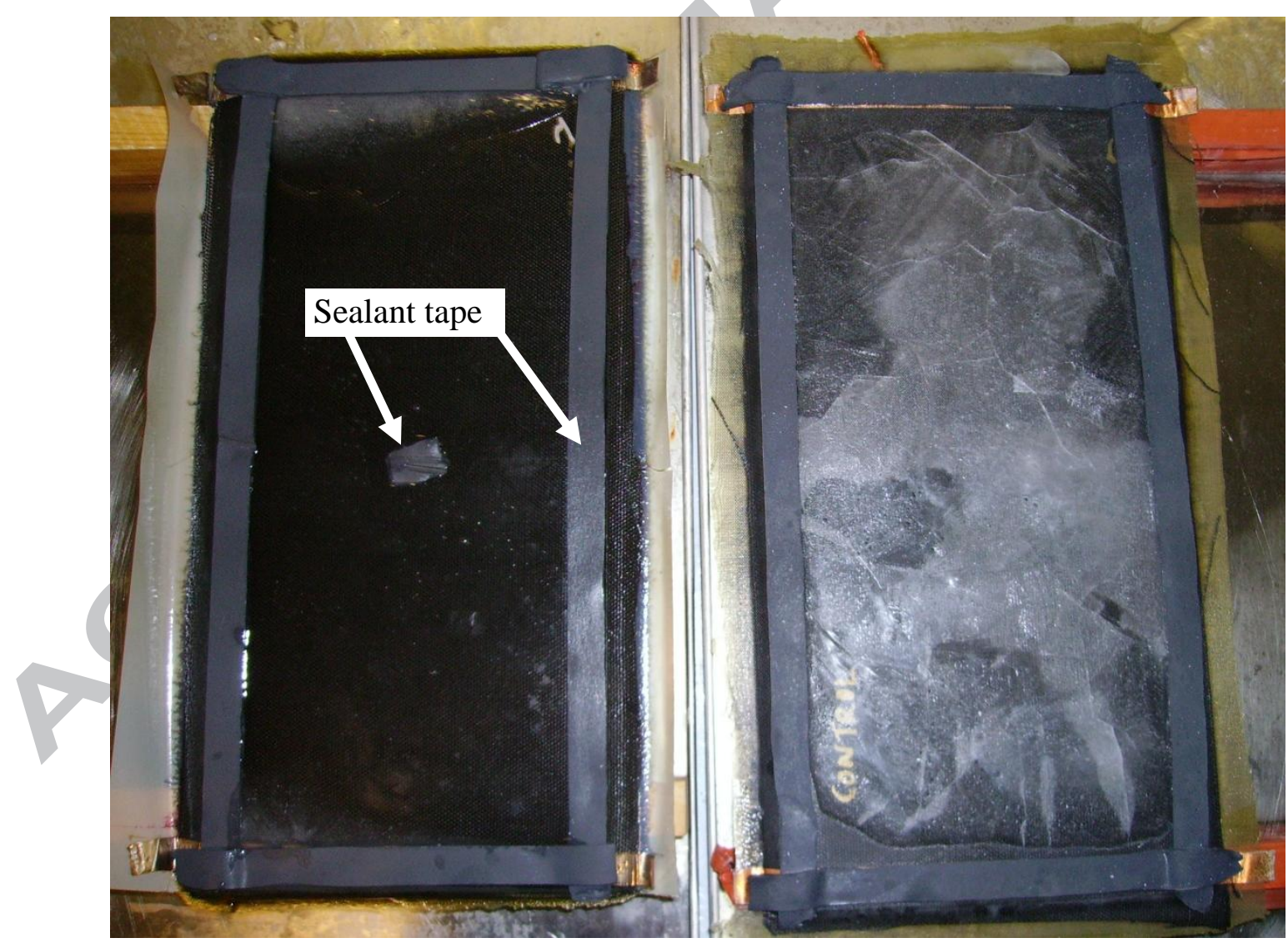

(a)

(b)

Figure 12: (a) Film insulated panel after de-icing (b) control panel. 

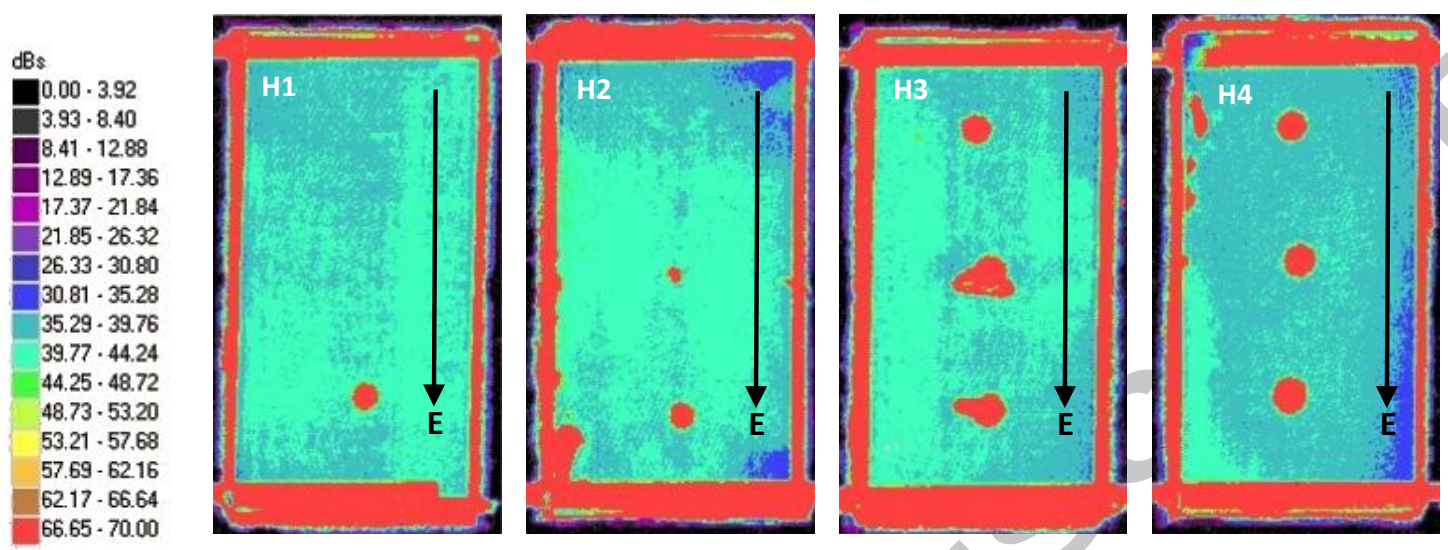

Figure 13: C-scans of polymer film insulated panels made from five-harness satin weave prepreg (AGP280/8552) with multiple impacts. The arrows indicate direction of increasing impact energy. 


\section{PANEL H3 BEFORE IMPACT}

After heating for $1 \min 30 \operatorname{secs}\left({ }^{\circ} \mathrm{C}\right)$

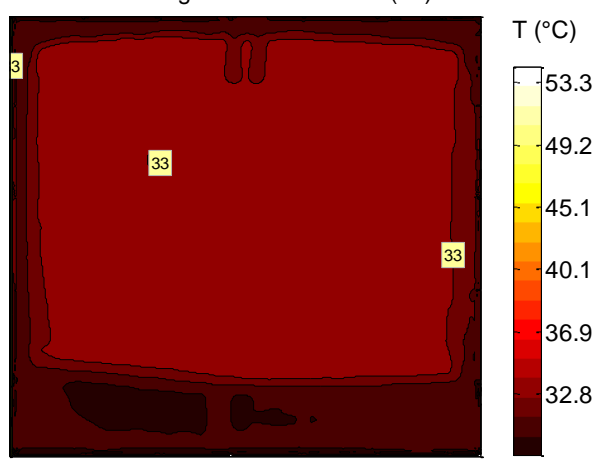

(a)

After heating for 3 mins $\left({ }^{\circ} \mathrm{C}\right)$

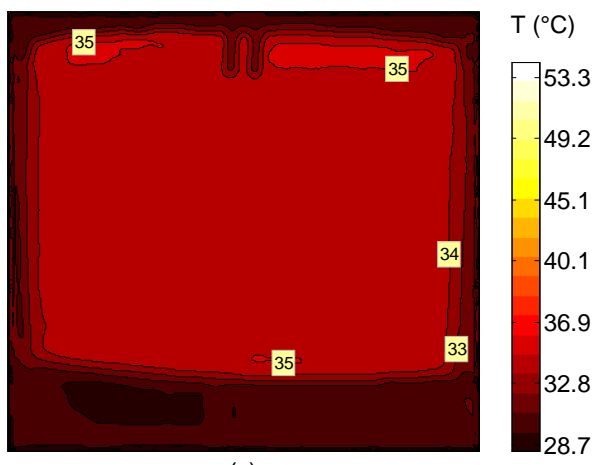

(c)

Stable $\left({ }^{\circ} \mathrm{C}\right)$

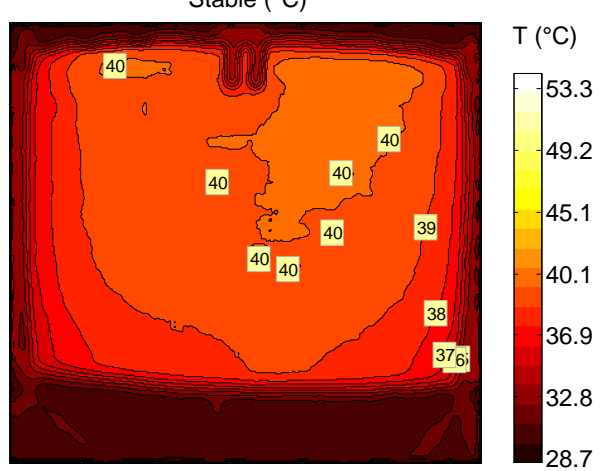

(e)

3 mins after power off $\left({ }^{\circ} \mathrm{C}\right)$

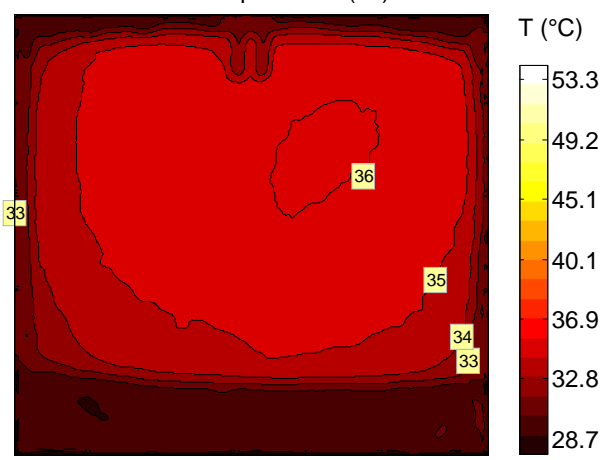

(g)
PANEL H3 AFTER IMPACT

After heating for $1 \mathrm{~min} 30 \operatorname{secs}\left({ }^{\circ} \mathrm{C}\right)$

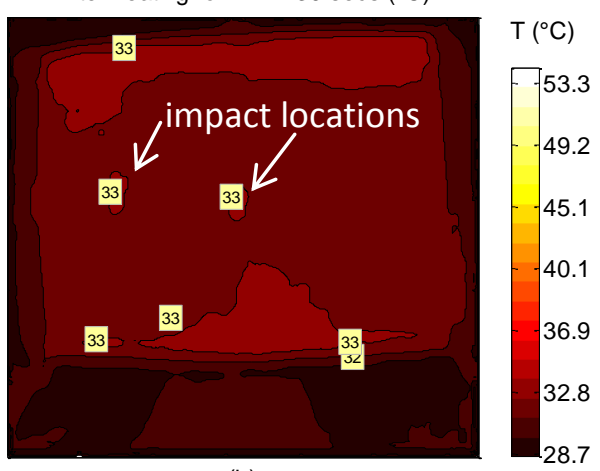

(b)

After heating for $3 \overline{\operatorname{mins}}\left({ }^{\circ} \mathrm{C}\right)$

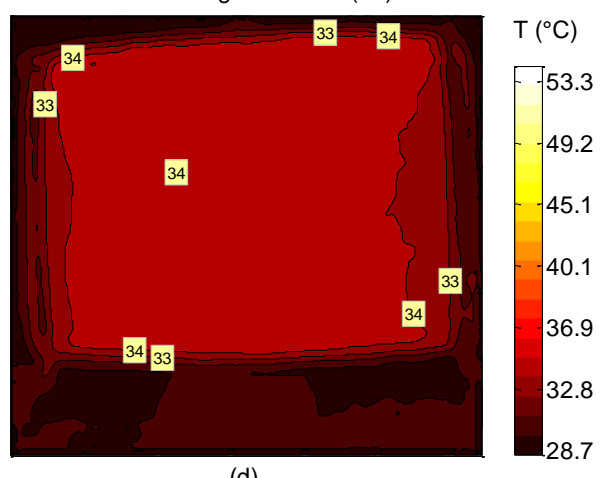

(d)

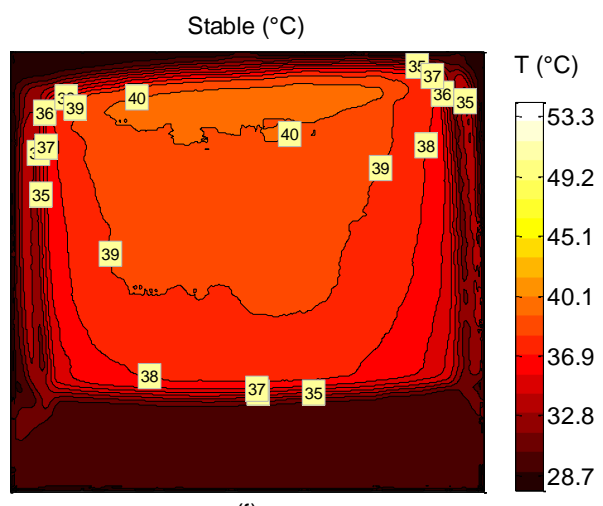

(f)

3 mins after power off $\left({ }^{\circ} \mathrm{C}\right)$

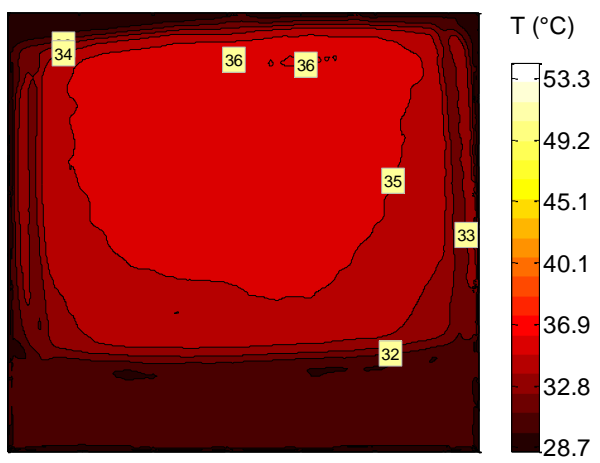

(h)

Figure 14 : Thermal imaging before and after impact of ECT panel. 
PANEL R2 BEFORE DAMAGE

After heating for $1 \min 30 \operatorname{secs}\left({ }^{\circ} \mathrm{C}\right)$

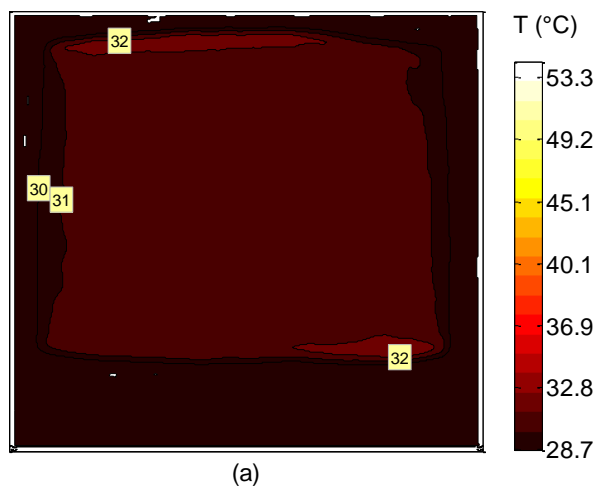

After heating for 3 mins $\left({ }^{\circ} \mathrm{C}\right)$

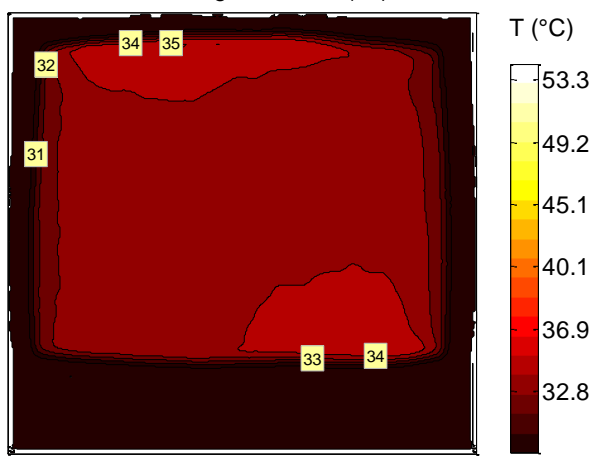

(c)

Stable $\left({ }^{\circ} \mathrm{C}\right)$

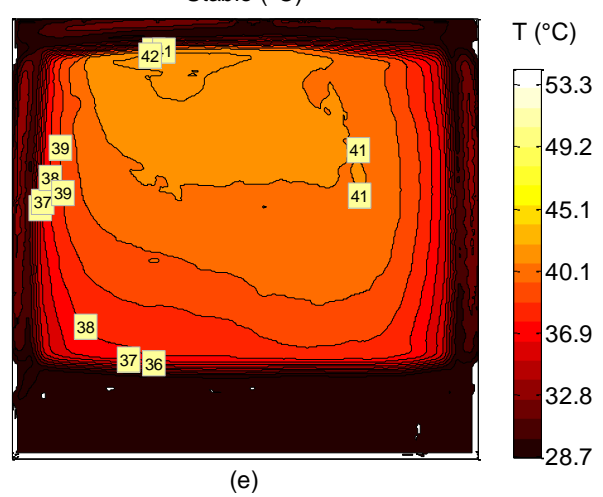

3 mins after power off $\left({ }^{\circ} \mathrm{C}\right)$

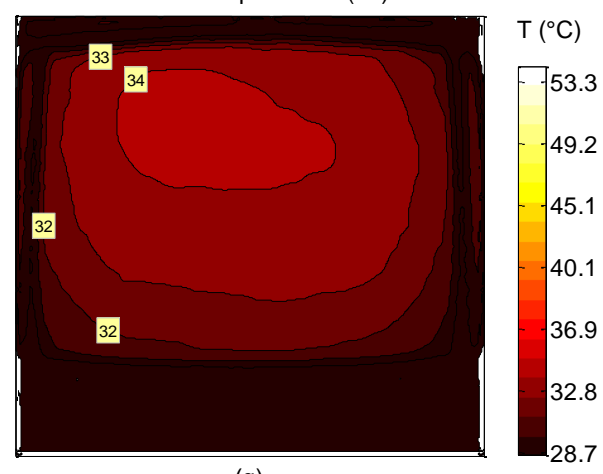

(g)
PANEL R2 AFTER REPAIR

After heating for $1 \min 30 \operatorname{secs}\left({ }^{\circ} \mathrm{C}\right)$

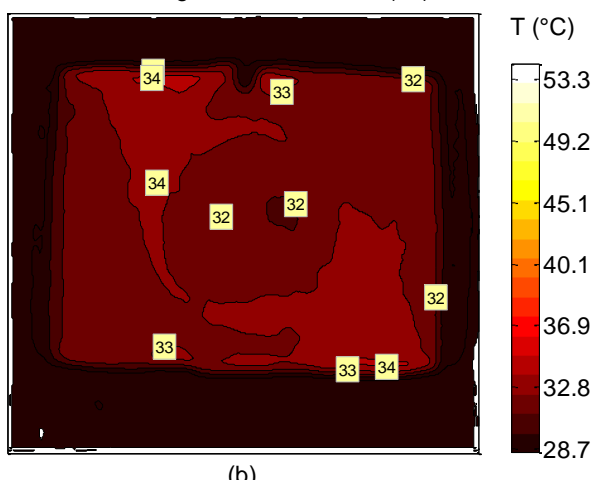

(b)

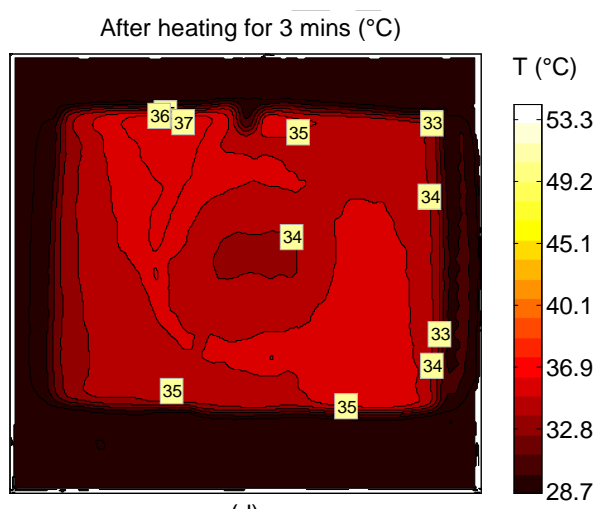

(d)

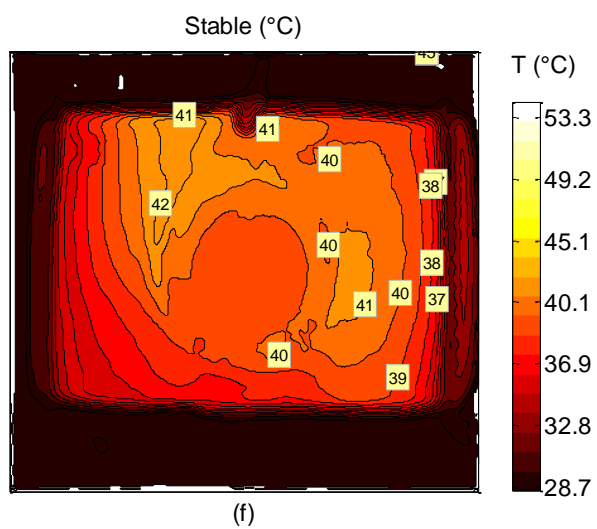

3 mins after power off $\left({ }^{\circ} \mathrm{C}\right)$

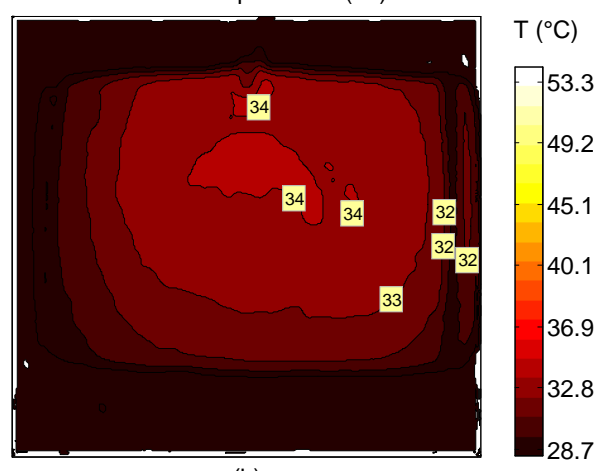

(h)

Figure 15 : Thermal imaging of repaired panel 
TABLES

Table 1: Heater panels with glass-fibre insulation.

\begin{tabular}{|l|l|l|l|l|}
\hline $\begin{array}{l}\text { Laminate } \\
\text { material }\end{array}$ & $\begin{array}{l}\text { Number of } \\
\text { panels }\end{array}$ & $\begin{array}{l}\text { Lay-up/nominal } \\
\text { thickness }\end{array}$ & $\begin{array}{l}\text { Insulation } \\
\text { medium }\end{array}$ & $\begin{array}{l}\text { Results: Heating } \\
\text { achieved? }\end{array}$ \\
\hline T300/913 & 2 & {$\left[0_{16}\right] / 2 \mathrm{~mm}$} & 2 glass-fibre plies & Yes \\
\hline AS4/8552 & 5 & {$[ \pm 45 / 0 / 90]_{4 \mathrm{~S}} / 4 \mathrm{~mm}$} & 2 glass-fibre plies & No \\
\hline AS4/8552 & 5 & {$[ \pm 45 / 0 / 90]_{4 \mathrm{~S}} / 4 \mathrm{~mm}$} & 3 glass-fibre plies & Yes in 4 of 5 panels \\
\hline
\end{tabular}

Table 2: Heater panels with polymer film insulation.

\begin{tabular}{|c|c|c|c|c|c|c|c|}
\hline $\begin{array}{l}\text { Base } \\
\text { laminate }\end{array}$ & $\begin{array}{l}\text { No. of } \\
\text { panels }\end{array}$ & $\begin{array}{l}\text { Lay-up/nominal } \\
\text { thickness }\end{array}$ & $\begin{array}{l}\text { Insulation } \\
\text { medium }\end{array}$ & $\begin{array}{l}\text { Plasma } \\
\text { treatment }\end{array}$ & $\begin{array}{l}\text { Layers of } \\
8552 \\
\text { resin film }\end{array}$ & $\begin{array}{l}\text { Bond } \\
\text { strength }\end{array}$ & $\begin{array}{l}\text { Result of } \\
\text { trial }\end{array}$ \\
\hline \multirow[t]{2}{*}{ AS4/8552 } & 1 & {$[ \pm 45 / 90 / 0] \mathrm{s} / 1 \mathrm{~mm}$} & $\begin{array}{l}\text { Melinex } \\
752\end{array}$ & none & 1 & $\begin{array}{l}\text { CFRP: } \\
\text { Strong }\end{array}$ & $\begin{array}{l}\text { Heating } \\
\text { effect } \\
\text { achieved }\end{array}$ \\
\hline & & & & & & $\begin{array}{l}\text { E-CT: } \\
\text { weak }\end{array}$ & \\
\hline \multirow[t]{2}{*}{ AS4/8552 } & 1 & {$[ \pm 45 / 90 / 0]_{\mathrm{s}} / 1 \mathrm{~mm}$} & $\begin{array}{l}\text { Melinex } \\
752\end{array}$ & Both sides & 1 & $\begin{array}{l}\text { CFRP: } \\
\text { strong }\end{array}$ & $\begin{array}{l}\text { Heating } \\
\text { effect } \\
\text { achieved }\end{array}$ \\
\hline & & & & & 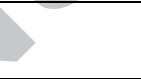 & $\begin{array}{l}\text { E-CT: } \\
\text { weak }\end{array}$ & \\
\hline \multirow[t]{2}{*}{ AS4/8552 } & 1 & {$[ \pm 45 / 90 / 0]_{\mathrm{s}} / 1 \mathrm{~mm}$} & $\begin{array}{l}\text { Mitsubishi } \\
\text { RNK }\end{array}$ & Both sides & 1 & $\begin{array}{l}\text { CFRP: } \\
\text { strong }\end{array}$ & $\begin{array}{l}\text { Heating } \\
\text { effect } \\
\text { achieved }\end{array}$ \\
\hline & & & & & & $\begin{array}{l}\text { E-CT: } \\
\text { weak }\end{array}$ & \\
\hline \multirow[t]{2}{*}{ AS4/8552 } & 1 & {$[ \pm 45 / 90 / 0] \mathrm{s} / 1 \mathrm{~mm}$} & $\begin{array}{l}\text { Victrex- } \\
1000 \text { 050S }\end{array}$ & E-CT side & 1 & $\begin{array}{l}\text { CFRP: } \\
\text { weak }\end{array}$ & $\begin{array}{l}\text { Heating } \\
\text { effect } \\
\text { achieved }\end{array}$ \\
\hline & & & & & & $\begin{array}{l}\text { E-CT } \\
\text { strong }\end{array}$ & \\
\hline \multirow[t]{2}{*}{ AS4/8552 } & 1 & {$[ \pm 45 / 90 / 0] \mathrm{s} / 1 \mathrm{~mm}$} & $\begin{array}{l}\text { Lumirror } \\
60.28\end{array}$ & Both sides & 2 & $\begin{array}{l}\text { CFRP: } \\
\text { strong }\end{array}$ & $\begin{array}{l}\text { Heating } \\
\text { effect } \\
\text { achieved }\end{array}$ \\
\hline & & & & & & $\begin{array}{l}\text { E-CT: } \\
\text { good }\end{array}$ & \\
\hline \multirow[t]{2}{*}{ AS4/8552 } & 1 & {$[ \pm 45 / 90 / 0]_{\mathrm{s}} / 1 \mathrm{~mm}$} & $\begin{array}{l}\text { Victrex- } \\
1000 \text { 050S }\end{array}$ & Both sides & 2 & $\begin{array}{l}\text { CFRP: } \\
\text { strong }\end{array}$ & $\begin{array}{l}\text { Heating } \\
\text { effect } \\
\text { achieved }\end{array}$ \\
\hline & 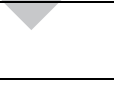 & & & & & $\begin{array}{l}\mathrm{E}-\mathrm{CT} \\
\text { strong }\end{array}$ & \\
\hline \multirow[t]{2}{*}{ AS4/8552 } & 1 & {$[ \pm 45 / 90 / 0] \mathrm{s} / 1 \mathrm{~mm}$} & $\begin{array}{l}\text { Melinex } \\
752\end{array}$ & Both sides & 2 & $\begin{array}{l}\text { CFRP: } \\
\text { strong }\end{array}$ & $\begin{array}{l}\text { Heating } \\
\text { effect } \\
\text { achieved }\end{array}$ \\
\hline & & & & & & $\begin{array}{l}\text { E-CT: } \\
\text { weak }\end{array}$ & \\
\hline \multirow[t]{2}{*}{ IM78552 } & 4 & {$[ \pm 45 / 90 / 0]_{4 \mathrm{~S}} / 4 \mathrm{~mm}$} & $\begin{array}{l}\text { Victrex } \\
1000 \text { 050S }\end{array}$ & Both sides & 2 & $\begin{array}{l}\text { CFRP: } \\
\text { strong }\end{array}$ & $\begin{array}{l}\text { Heating } \\
\text { effect } \\
\text { achieved }\end{array}$ \\
\hline & & & & & & $\begin{array}{l}\text { E-CT: } \\
\text { strong }\end{array}$ & \\
\hline
\end{tabular}


Table 3: Anti-icing test results for glass-fibre insulated panels.

\begin{tabular}{|c|c|c|c|c|c|c|c|c|c|c|c|}
\hline \multirow[t]{2}{*}{ Panel } & \multirow{2}{*}{$\begin{array}{l}\begin{array}{l}\text { Stable* } \\
\text { temp }\end{array} \\
\left({ }^{\circ} \mathrm{C}\right)\end{array}$} & \multirow{2}{*}{$\begin{array}{l}\text { Current } \\
\text { (A) }\end{array}$} & \multirow{2}{*}{$\begin{array}{l}\text { Voltage } \\
(\mathrm{V})\end{array}$} & \multirow{2}{*}{$\begin{array}{l}\text { Power } \\
\text { density } \\
\left(\mathrm{W} / \mathrm{m}^{2}\right) \\
\end{array}$} & \multicolumn{6}{|c|}{$\begin{array}{l}\text { Panel Temp }\left({ }^{\circ} \mathrm{C}\right) \text { as a function of time } \\
\text { (min) }\end{array}$} & \multirow[t]{2}{*}{ Observations } \\
\hline & & & & & 10 & 20 & 30 & 40 & 50 & 60 & \\
\hline $1 \mathrm{G}$ & -10 & 2.6 & 6.7 & 430 & 4 & 2 & 1 & 0 & 0 & 0 & $\begin{array}{l}\text { Water on the } \\
\text { verge of } \\
\text { freezing. Ice in } \\
\text { bottom left } \\
\text { corner }\end{array}$ \\
\hline $1 G$ & -10 & 2.8 & 7.3 & 505 & 8 & 5 & 4 & 4 & 4 & 4 & $\begin{array}{l}\text { No ice and no } \\
\text { significant } \\
\text { evaporation }\end{array}$ \\
\hline $1 G$ & -20 & 3.8 & 9.2 & 863 & 2 & 2 & 2 & 2 & 2 & 2 & $\begin{array}{l}\text { lce in bottom } \\
\text { left corner }\end{array}$ \\
\hline $2 G$ & -10 & 2.8 & 7.3 & 505 & 0 & 1 & 1 & 0 & 1 & 0 & $\begin{array}{l}\text { Water on the } \\
\text { verge of } \\
\text { freezing. } \\
\text { Small amount } \\
\text { of ice in } \\
\text { bottom left } \\
\text { corner }\end{array}$ \\
\hline $2 G$ & -20 & 3.8 & 9.1 & 854 & 5 & 6 & 6 & 5 & 5 & 5 & $\begin{array}{l}\text { No ice and no } \\
\text { significant } \\
\text { evaporation }\end{array}$ \\
\hline $3 G$ & -10 & 3.0 & 7.7 & 570 & 13 & 9 & 9 & 7 & 7 & 7 & $\begin{array}{l}\text { No ice and no } \\
\text { significant } \\
\text { evaporation }\end{array}$ \\
\hline $3 G$ & -20 & 3.8 & 9.1 & 854 & 7 & 5 & 5 & 3 & 3 & 3 & $\begin{array}{l}\text { Ice in bottom } \\
\text { left corner }\end{array}$ \\
\hline
\end{tabular}

* Ambient temperature

Table 4: Anti-icing test results for Victex polymer film insulated panels.

\begin{tabular}{|c|c|c|c|c|c|c|c|c|c|c|c|}
\hline \multirow[t]{2}{*}{ Panel } & \multirow{2}{*}{$\begin{array}{l}\begin{array}{l}\text { Stable } \\
\text { temp }\end{array} \\
\left({ }^{\circ} \mathrm{C}\right)\end{array}$} & \multirow{2}{*}{$\begin{array}{l}\text { Current } \\
\text { (A) }\end{array}$} & \multirow{2}{*}{$\begin{array}{l}\text { Voltage } \\
\text { (V) }\end{array}$} & \multirow{2}{*}{$\begin{array}{l}\text { Power } \\
\text { density } \\
\left(\mathrm{W} / \mathrm{m}^{2}\right)\end{array}$} & \multicolumn{6}{|c|}{$\begin{array}{l}\text { Panel Temp }\left({ }^{\circ} \mathrm{C}\right) \text { as a function of time } \\
\text { (min) }\end{array}$} & \multirow[t]{2}{*}{ Observations } \\
\hline & & & & & 10 & 20 & 30 & 40 & 50 & 60 & \\
\hline $1 \mathrm{~F}$ & -10 & 2.0 & 8.2 & 420 & 6 & 6 & 6 & 5 & 5 & 5 & $\begin{array}{l}\text { No ice and no } \\
\text { significant } \\
\text { evaporation }\end{array}$ \\
\hline $1 \mathrm{~F}$ & -20 & 3.2 & 10.6 & 838 & 9 & 8 & 7 & 7 & 7 & 7 & $\begin{array}{l}\text { No ice but a } \\
\text { small amount } \\
\text { of evaporation } \\
\text { recorded }\end{array}$ \\
\hline $2 \mathrm{~F}$ & -10 & 2.2 & 8.1 & 440 & 10 & 5 & 4 & 4 & 4 & 4 & $\begin{array}{l}\text { No ice and no } \\
\text { significant } \\
\text { evaporation }\end{array}$ \\
\hline $2 \mathrm{~F}$ & -20 & 3.2 & 10.6 & 838 & 5 & 6 & 6 & 6 & 6 & 6 & $\begin{array}{l}\text { No ice and no } \\
\text { significant } \\
\text { evaporation }\end{array}$ \\
\hline $3 F$ & -10 & 2.2 & 8.0 & 435 & 3 & 2 & 2 & 2 & 1 & 1 & $\begin{array}{l}\text { No ice and no } \\
\text { significant } \\
\text { evaporation }\end{array}$ \\
\hline $3 F$ & -20 & 3.2 & 10.6 & 838 & 4 & 4 & 3 & 3 & 3 & 3 & $\begin{array}{l}\text { No ice and no } \\
\text { significant } \\
\text { evaporation }\end{array}$ \\
\hline
\end{tabular}

* Ambient temperature 
Table 5: De-icing test results for glass-fibre insulated panels.

\begin{tabular}{|c|c|c|c|c|c|c|c|}
\hline Panel & $\begin{array}{l}\text { Stable }{ }^{*} \\
\text { temp }\end{array}$ & Current & Voltage & $\begin{array}{l}\text { Power } \\
\text { density }\end{array}$ & $\begin{array}{l}\text { Pan } \\
\text { func }\end{array}$ & $\begin{array}{l}\left({ }^{\circ} \mathrm{C}\right) \text { as a } \\
\text { ime (min) }\end{array}$ & Observations \\
\hline & $\left({ }^{\circ} \mathrm{C}\right)$ & (A) & (V) & $\left(\mathrm{W} / \mathrm{m}^{2}\right)$ & 0 & 60 & \\
\hline $1 G$ & -20 & 3.8 & 9.2 & 863 & -20 & -2 & $\begin{array}{l}\text { Approximately } \\
\text { half the ice } \\
\text { melted }\end{array}$ \\
\hline $2 G$ & -20 & 4.0 & 10.2 & 1007 & -18 & 8 & $\begin{array}{l}\text { Approximately } \\
\text { two thirds of } \\
\text { the ice melted }\end{array}$ \\
\hline $3 G$ & -20 & 3.8 & 9.9 & 929 & -20 & 7 & $\begin{array}{l}\text { Approximately } \\
\text { two thirds of } \\
\text { the ice melted }\end{array}$ \\
\hline
\end{tabular}

${ }^{*}$ Ambient temperature

Table 6: De-icing test results for film insulated panels.

\begin{tabular}{|c|c|c|c|c|c|c|c|}
\hline Panel & $\begin{array}{l}\text { Stable }^{*} \\
\text { temp }\end{array}$ & Current & Voltage & $\begin{array}{l}\text { Power } \\
\text { density }\end{array}$ & $\begin{array}{l}\text { Pane } \\
\text { func }\end{array}$ & $\begin{array}{l}\left({ }^{\circ} \mathrm{C}\right) \text { as a } \\
\text { ime (min) }\end{array}$ & Observations \\
\hline & $\left({ }^{\circ} \mathrm{C}\right)$ & (A) & (V) & $\left(W / m^{2}\right)$ & 0 & & \\
\hline $1 \mathrm{~F}$ & -20 & 3.0 & 11.0 & 830 & -22 & 5 & $\begin{array}{l}\text { Majority of the } \\
\text { ice melted with } \\
\text { the exception } \\
\text { of a small area } \\
\left(2 \mathrm{~cm}^{2}\right) \\
\text { towards the } \\
\text { front of the } \\
\text { chamber and a } \\
\text { larger piece of } \\
\text { ice at the back } \\
\text { near the } \\
\text { coolant entry. }\end{array}$ \\
\hline $2 \mathrm{~F}$ & -20 & 3.2 & 10.8 & 853 & -22 & 5 & $\begin{array}{l}\text { Most of the ice } \\
\text { melted. A thin } \\
\text { layer of ice } \\
\text { covered one } \\
\text { third of the } \\
\text { panel towards } \\
\text { the back of the } \\
\text { chamber. }\end{array}$ \\
\hline $3 F$ & -20 & 3.2 & 10.5 & 815 & -21 & 5 & $\begin{array}{l}\text { Majority of the } \\
\text { ice melted with } \\
\text { the exception } \\
\text { of two small } \\
\text { strips at either } \\
\text { end of the } \\
\text { specimen. }\end{array}$ \\
\hline
\end{tabular}

${ }^{*}$ Ambient temperature 